\title{
A stochastic approach to rhotic variation in Spanish codas
}

\author{
Mark Gibson \\ Universidad de Navarra \\ mgibson@unav.es
}

\begin{abstract}
Submitted: 02/09/2013. Accepted: 01/12/2014. Available on line: 18/11/2015
Citation / Cómo citar este artículo: Gibson, M. (2015). A stochastic approach to rhotic variation in Spanish codas. Loquens, 2(1), e015. doi: http://dx.doi.org/10.3989/loquens.2015.015
\end{abstract}

\begin{abstract}
A stochastic analysis using aerodynamic and temporal variables is presented to explain tap/trill variation in Spanish codas. Simultaneous intraoral pressure $\left(\mathrm{P}_{\mathrm{o}}\right)$, translingual flow $(\mathrm{F})$ and acoustic signals were obtained for two native speakers of Peninsular Spanish performing a rate-controlled reiterative task. Data were analyzed using linear mixed effects models fitted with random effects for speaker and repetition. The results show that tongue height and tongue anteriority of the preceding vowel affect the timing and aerodynamic parameters of the rhotic onset gesture, but the phonological specifications of the following consonants do not. Continuous variables were fit into a Bayesian logit regression model using noninformative priors which shows that tap/trill variation in coda can be predicted in part from aerodynamic and temporal parameters. Such a proposal obviates the need to resort to positional constraints to explain tap/trill variation in codas.
\end{abstract}

Keywords: aerodynamic parameters; Spanish rhotics; variation.

RESUMEN: Análisis estocástico de la variación de las róticas en posición de coda en español.- Se presenta un análisis estocástico con variables aerodinámicas y temporales para explicar la variación de las róticas en posición implosiva en español. Las señales acústicas, de presión orofaríngea y flujo traslingual, fueron obtenidas simultáneamente de dos sujetos nativos de habla hispana en una tarea de repetición controlada. Los datos fueron analizados utilizando una serie de modelos lineales de efectos mixtos tomando como efectos aleatorios programados tanto la variable hablante como repetición. Los resultados demuestran que la postura de la lengua en la vocal que precede a la rótica afecta a la temporización y los parámetros aerodinámicos del gesto inicial de la rótica. Las variables continuas se programaron en un modelo de regresión logística bayesiana utilizando una distribución de probabilidades $a$ priori no informativa que demuestra que la variación entre la vibrante simple y la vibrante múltiple en posición implosiva en español es predecible en parte por los parámetros aerodinámicos y temporales. Tal propuesta hace innecesario explicar la variación de las róticas en posición implosiva con un modelo determinista que regule el surgimiento de segmentos en determinadas posiciones fonológicas.

Palabras clave: parámetros aerodinámicos; róticas en español; variación.

\section{THE ARTICULATORY AND AERODYNAMIC CHARACTERISTICS OF SPANISH RHOTICS}

Spanish has two quasi-contrasting rhotics, the apical alveolar tap [r] and the apical alveolar trill [r]. Taps have been described as a coordinated progression of the tongue tip toward the alveolar ridge which makes a singular contact in the post-dental region (Ladefoged \& Maddieson, 1996). Trills, in contrast, involve a short series of occlusions against the alveolar ridge, producing a tense, controlled and highly constrained gesture (Recasens, 1991). And whereas the simple tap [r] requires lingual muscular control to carry out the tongue tip gesture, trill instantiation and maintenance depends on the antagonistic relationship between torsional force of the tongue mass and aerodynamic factors (Barry, 1997; Catford, 1977; Ladefoged \& Maddieson, 1996; Recasens, 1991; Spajić, Ladefoged, \& Bhaskararao, 1996; Solé, 2002). Taps show less predorsum lowering and postdorsum retraction than trills (Recasens \& Pallarès, 1999), while the tongue body is more restricted for trills than for taps (Recasens, 1991). Further, there is believed to be a slight velar gesture inherent to the trill which constrains coarticulation with neighboring vowels (Recasens, 1987). Both rhotics con- 
tain a non-syllabic, vocoid-like element which may be audible in certain contexts (Hall, 2006; Harms, 1976; Levin, 1987; Quilis, 1970, 1993; Schmeiser, 2009; Warner, Jongman, Cutler, \& Mücke, 2001) and is attested cross-linguistically (for Catalan rhotics, see Recasens \& Espinosa, 2007; for Hungarian, see Vago \& Gósy, 2007; for Modern Greek, see Baltazani \& Nicolaidis, 2011, 2013; for Polish, see Stolarski, 2011, June; for Romanian, see Avram, 1993; for Serbo-Croatian, see Gudurić \& Petrović, 2005; for Slovak, see Pavlík, 2008; for Spanish, see Bradley \& Schmeiser, 2003; Ramírez, 2006; Schmeiser, 2009).

The mechanics of trills have been outlined extensively in Barry (1997), Catford (1977), Ladefoged and Maddieson (1996), and Spajić, Ladefoged, and Bhaskararao (1996) while Solé (2002) characterizes the specific oropharyngeal pressure parameters for voiced and voiceless apical trills. As the tongue sides rise toward the upper molars, there is a lowering of the tongue dorsum to initiate tongue tip vibration. The tongue tip approaches the alveolar target, causing an increase in oropharyngeal pressure behind the linguopalatal constriction. Eventually, this pressure builds up to the point that its force becomes more powerful than the mass and torsional force of the contracted muscles of the tongue tip, pushing the articulator down away from the alveolar ridge and allowing airflow to escape. The tongue tip returns to the alveolar ridge due to the Bernoulli effect, taking the form of a selfsustained vibratory system.

Aerodynamic requirements for voiced trills are severely constrained in order to sustain muscular and laryngeal vibration (Solé, 2002). Solé (2002) demonstrated that slight perturbations to the parameters needed for vibration lead to the interruption of trilling and voicing. She showed that gradual reductions in oropharyngeal pressure extinguished voiced trills earlier than voiceless trills and the window of permissible pressure parameters for trills is narrower than that of fricatives, suggesting that voiceless trills tend to be more impervious to changes in aerodynamic conditions than voiced trills.

\section{RHOTIC VARIATION IN SPANISH CODAS: CONTEXTUAL PARAMETERS VERSUS POSITIONAL CONSTRAINTS}

Rhotic distribution is generally predictable in Spanish. The simple tap [ $\mathrm{r}]$ can appear as a singleton onset word-internally and as the second gesture of a complex onset word-initially and word-internally. In codas $[r]$ emerges frequently and can serve as the first gesture in one of only a few tokens which contain a complex coda: perspicaz, 'keen'. Trills contrast with the tap in word-internal onsets, while the trill appears exclusively in wordinitial position. In syllable-final position, the tap and trill contrast in a paradigm of free variation, although taps are generally preferred.

A number of factors influence variation in codas. From the point of view of perception, coda consonants are less salient than those found in onsets and hence play an inferior role in lexicon access and retrieval (Beckman, 1998), meaning consonants may vary more freely without signaling a rupture in communication. As regards spatiotemporal coordination, it has been proposed that coda gestures are phased linearly $\left(180^{\circ}\right)$ in relation to the preceding vowel (Browman \& Goldstein, 1986, and many studies since), which translates to a reduction in stability compared to onset gestures (Byrd, 1996; Goldstein, Byrd, \& Saltzman, 2006; Goldstein, Nam, Saltzman, \& Chitoran, 2008, April). Due to this decreased stability, codas are often susceptible to non-categorical variation when speech rate increases (Goldstein, Pouplier, Chen, Saltzman, \& Byrd, 2007; Pouplier, 2007a, 2007b), and are acquired later than onsets, often undergoing processes of substitution and deletion not found for onsets (Demuth \& Fee, 1995; Fikkert, 1994; Gnanadesikan, 1996; Levelt, Schiller, \& Levelt, 2000; Salidis \& Johnson, 1997; Vihman \& Ferguson, 1987). Syllable-final consonants appear to be especially prone to articulatory reduction (Ohala \& Kawasaki, 1984) due to modifications of lingual posture and constriction degree (Recasens, 2004) which may lead to diachronic changes in the phonology (Browman \& Goldstein, 1995; Fougeron, 1999; Solé, 2003). With regard to aerodynamics it was suggested that drops in subglottal pressure for coda fricatives may explain their tendency to lenite (Solé, 2003). In stuttering patients, it has been found that the emergence of a syllable-final gesture may trigger the destabilization of gesture sequences, codas being likely candidates for gestural reorganization (Huinck, van Lieshout, Peters, \& Hulstijn, 2004).

Coda variation is one of the defining characteristics of both standard and non-standard dialects in Spanish. Aside from the tap/trill contrast, attested processes include aspiration and deletion of coda /s/ (see Kochetov \& Colantoni, 2011; Lipski, 1994; Romero, 1995, for especially informative reviews), the optional velarization of $/ \mathrm{n} /$ (Canfield, 1960, 1981; Darias Concepción, Ruisánchez Regalado, \& Dohotaru, 1997; Lipski, 1987, 1994; López Morales, 1981; Wireback, 1999), the non-standard lateralization of /r/ (D'Introno, Rojas, \& Sosa, 1979; Marrero, 1988; Quilis-Sanz, 1998), the non-standard rhoticization of /1/ (López Morales, 1983; Quilis, 1999; Willis, 2006), devoicing of word-final obstruents (González, 2002) and complete deletion of a number of consonants.

The majority of studies addressing the distribution of rhotics in syllable-final position in Spanish have been limited to a descriptive and/or theoretical approach, focusing more on the dialectal idiosyncrasies of the rhotics than the mechanical processes that trigger rhotic variation (see Bradley \& Willis, 2012; Vásquez Carranza, 2006). Colina (2010) envisages tap emergence in coda as a function of positional constraints which prohibit the trill from emerging in coda. A number of important asymmetries, however, challenge a deterministic approach to tap/trill variation based on positional constraints. First, the realization of the trill for the tap does not comport with the general tendency toward lenition in Spanish codas, lenition understood as the reduction of articulatory effort as 
per Kirchner (1998). Second, there is no lexical, semantic or syntactic ambiguity attributed to the realization of one variant over another which might suggest that tap/trill variation is actually a linguistic phenomenon (as opposed to a strictly mechanical process) as there is with lateralization/rhoticization and consonant deletion. Third, such a proposal ignores the random effects from the phonetic environment which may also condition variation. These asymmetries suggest that tap/trill variation may not be an objective function of the productive Spanish grammar, but rather is determined primarily, though maybe not exclusively, from the context-dependent articulatory and aerodynamic parameters established by the phonetic environment.

There are independent reasons, however, to espouse a stochastic approach of tap/trill variation which takes into account the context-dependent phonetic parameters which may favor or discourage trilling in certain environments. It has been reported that the articulatory settings for vowels condition the aerodynamic patterns of neighboring consonants (Chang et al., 1999; Fischer-Jørgensen, 1972; Klatt, 1975; Koenig \& Fuchs, 2007; Netsell, Lotz, DuChane, \& Barlow, 1991). Intra-oral pressure discharge for voiceless stops, for example, was shown to be slower preceding high vowels, possibly due to the higher degree of impedance (Chang et al., 1999; Fischer-Jørgensen, 1972; Koenig \& Fuchs, 2007). Peak intraoral pressure values have been found to be lower in repetitions of voiceless labial stops followed by low vowels versus high vowels (Netsell et al., 1991) due to a more constricted oral cavity for high vowels. Solé (2002) found significantly higher mouthflow rates for trills coarticulated with a preceding [i], as compared to [a], yet effects were not consistent across speakers. Voice onset time has been found to be significantly longer leading into high-vowels as compared to low vowels (Klatt, 1975). To date, the effects of tongue anteriority on the aerodynamic parameters of neighboring consonants have received scant attention.

Given the precise aerodynamic and articulatory requirements for trilling, it is reasonable to expect the articulatory setting of the preceding vowel to affect the temporal and aerodynamic parameters of a following rhotic, and possibly play some role in tap/trill variation in Spanish.

In a similar way, the articulatory settings of vowels have also been found to affect coordination with neighboring consonants. Velar stops have been shown to be more fronted when followed by front vowels (Bloomfield, 1956). Later it was shown that the degree of fronting varies considerably across languages (Arbisi-Kelm, Beckman, Kong, \& Edwards, 2008). Studying the prebabbling stage of infants, Davis and MacNeilage (1995), MacNeilage (1998) and MacNeilage and Davis (1990) found that of all possible consonant/vowel combinations, velar consonants co-occurred more with back vowels, coronal consonants emerge more often with front vowels, while labial consonants patterned more with central vowels, showing a biomechanical preference for CV sequences with high degrees of coarticulation. It has also been proposed that vowels with higher jaw settings are more resilient to coarticulatory effects, while being more likely to influence surrounding gestures (Recasens, 1985). Low vowels, on the other hand, are least resistant to coarticulatory effects, while being less likely to influence neighboring gestures. In the context of the current study, the degree of coarticulation may yield aerodynamic conditions which favor or discourage spontaneous trilling, in the sense that a higher degree of coarticulation between the vowel and rhotic onset could provide a longer temporal window in which to achieve the precise aerodynamic conditions required for trilling. High front vowels (fronting/predorsum raising) present conflicting articulatory demands on the lingual settings for trills (backing/predorsum lowering), which would constrain coarticulation. The tongue posture required for trilling may be less constrained, however, to coarticulate with mid-low and back vowels given their articulatory similarities. Thus if the degree of coarticulation is linearly related to mouthflow, and if mouthflow is a predictor of trilling, then a higher probability of spontaneous trilling following mid and back vowels would be expected.

The constriction degree of the following consonant plays a role in establishing articulatory parameters which may favor one rhotic variant over another by initiating modifications of vocal tract width which instigate alterations in oropharyngeal pressure and airflow. Voiceless stops, for example, have a narrower and more constricted tract than their voiced counterparts (Proctor, Shadle, \& Iskarous, 2010). The larger pharyngeal volume for voiced stops is needed for vocal fold vibration. As airflow exits the lungs, friction causes vibration of the vocal folds, slowing the rate of air by absorbing the energy of the airflow. Lower pharyngeal volume for voiceless stops allows laminal airflow to increase rapidly, and produce a higher pressure buildup behind the tongue tip as the target gesture is reached, which may compete with the aerodynamic requirements for trill instantiation.

Likewise, the constriction location of a following consonant imposes both temporal and physical constraints on the preceding rhotic gesture. (For an especially enlightening review of the effects of following consonants on tap/trill variation, see Blecua, 2001.) In a sequence /r.d/, for example, it has been shown that no articulatory overlap is possible due to the fact that both consonant gestures involve the same primary articulator (Romero, 1996). The transition from a consonant with a relatively high stiffness specification $([+$ stiff $])$ to a consonant which is characterized as [-stiff] implies a reciprocal modification of torsional force in order to maintain the sequence stable. This stiffness/force equilibrium is well supported in classical rotational mechanics. Shadmehr and Arbib (1992) formulate the stiffness/force relationship in a biomechanical framework for a single joint system at isometric conditions, demonstrating that muscle stiffness must increase at least linearly with force in order to maintain stability. In the case of $/ \mathrm{r} . \mathrm{d} /$, a damping behavior akin to that employed for the realization of the tap would be more adequate as opposed to vibration in order 
to maintain equilibrium between tongue mass force and stiffness. In this context, the emergence of a trill should be discouraged by the phonetic environment. In sequences in which the consonant following the rhotic involves an active articulator from a distinct articulatory tier, however, the tongue tip for the rhotic is less constrained, or more free, to vary since the physical characteristics of the gestures do not make simultaneous demands on the same muscle mass. This assertion, however, is refuted by Blecua's (2001) extensive study of Spanish rhotics where it was found that rhotics followed by laterals (same active articulatory as the rhotic), then nasals and stops, showed the highest percentages of trilling.

The remainder of this article attempts to characterize the aerodynamic and temporal parameters (mouthflow) of apical taps and trills in syllable-final position. Consideration is directed toward the specific effects of the preceding vowel on the pre-closure phase of the rhotic, though the effects of the following consonant are also examined. Given that the parameters for intraoral pressure in voiced apical trills have been thoroughly outlined in Solé (2002), this article focuses attention on mouthflow parameters. Mouthflow patterns are especially informative because of their relation to glottal width, oropharyngeal pressure (mouthflow grows linearly with oropharyngeal pressure $[=\Delta \mathrm{P}]$, Solé, 2002), oral volume and transglottal flow (Isshiki, 1964), in addition to providing indirect evidence with which to infer articulatory movement. Such a focus allows us to corroborate the effects of the vocalic environment on the aerodynamic conditions of the rhotic while presenting new kinetic data which may be relevant to tap/trill variation.

\section{EXPERIMENTS}

\subsection{Data}

A corpus of nonce words was used in order to control for the effects of stress and syllable structure on the aerodynamic and temporal patterns of the rhotics. To control for speech rate effects, a rate controlled reiterative task was employed in which subjects synchronized their utterances with a digital metronome set at 80 beats per minute.

The corpus included rhotic/C combinations in which $\mathrm{C}$ was specified for [lips], [tongue tip] or [tongue body]. Data were collected for both voiced and voiceless pairs: $/ \mathrm{p}, \mathrm{b} /, / \mathrm{t}, \mathrm{d} /, / \mathrm{k}, \mathrm{g} /$. The sequences were tested with all possible vowel combinations for Spanish. Three repetitions were solicited for each token and speaker (3 repetitions $\mathrm{x}$ 150 tokens $\times 2$ speakers $=900$ tokens).

\subsection{Subjects}

The subjects were two native Peninsular Spanishspeakers from standard dialectal regions of Spain (Madrid and the Basque Country). Subject 1 (JLG) was a male aged 27 from Madrid and Subject 2 (BRA) was a female aged 29 from Bilbao. Subject 2 was chosen specifically because this particular variety of Spanish is characterized by a high distribution of trilled coda rhotics (Alonso, 1945, cited in Hualde, 2004). However, a higher distribution of coda trills due to the linguistic background of the subject does not necessarily entail differences in the trills internal mechanics (see Solé, 2002).

\subsection{Methodology}

Aerodynamic signals were obtained at a sample frequency of $6250 \mathrm{~Hz}$ using a wide-range, grid pneumotachograph to measure mouthflow and a catheter inserted between the lips to measure changes in intraoral air pressure (EVA2 ${ }^{\mathrm{TM}}$ system). The instrument was calibrated before each speaker. Simultaneous audio signals were also obtained to analyze formant frequencies.

Aerodynamic instrumentation was chosen specifically due to the high aerodynamic setting for rhotics and to avoid perturbation of the tongue tip during articulation, which may occur with other methods such as EMA (Electromagnetic Midsagittal Articulography) or EMG (electromyography). Additionally, an integral part of this study is to understand the behavior of the tongue when linguopalatal contact is not being realized. For this reason, EPG (electropalatography) was rejected. Ultrasound was excluded due to the fact that the speed of the articulatory movements involved in trilling are often times unobservable due to low temporal resolution.

A computer program, Phonedit (v. 4.2.0.1; Laboratoire Parole \& Langage, 2014), from the Université d'Aix-en-Provence, France was employed for post-data analysis while the acoustic signal was analyzed using Praat (v. 5.3.5.1). Statistics were performed using the $\mathrm{R}$ statistics software package (v. 3.2.1).

To categorize data before analysis, the aerodynamic and acoustic signals were examined by two trained Spanish-speaking phoneticians and a student of phonetics. Tokens were classified into one of three groups: taps, voiced apical trills and voiceless apical trills. Discrepancies arose between all three categories. In some instances the aerodynamic record seemed to indicate the existence of a weak trill. In this case, the problematic tokens were presented to untrained Spanish-speakers in order to make a determination based on a native speaker's perception of the unit (see Stevens' $[1972,1989]$ quantal theory for a discussion on the correlation between phonological distinction, production variation and perceptual salience).

In other instances, the definition of voiced versus voiceless trills was problematic since the initiation of the trill was voiced, but the trill itself was predominantly voiceless. These were excluded from the statistical analyses due to the different dynamic profiles of voiced and voiceless trills. It is interesting to note that all of these examples pertained to the same context: high-front vowels followed by the rhotic. This point is relevant in relation to findings which suggest that a higher larynx for 
high vowels (Klatt, 1975), along with higher supraglottal impedance (Chang et al., 1999), can result in a cessation of phonation in high-vowel (especially front) contexts.

\subsection{Measurements}

Within the pre-closure phase, latencies were obtained for (1) vowel onset to rhotic onset, (2) rhotic onset to alveolar contact, and (3) vowel onset to alveolar contact. Vowel onset was defined by the initiation of phonation. Mouthflow parameters included peak flow (Max_F), as well as average flow (Avg_F). Average flow was obtained by summing mouthflow values obtained at quarterly temporal landmarks marked on the aerodynamic signal over the span of the onset gesture and dividing the sum by the total number of landmarks.

Timestamps were annotated manually on the filtered aerodynamic signal (see Figure 1). The vowel was delimited from the rhotic by marking the beginning of mouthflow and phonation (signaling the beginning of the vowel gesture) and the change in mouthflow contour (marking the onset of $/ \mathrm{r} /$ ). The end of the rhotic onset was determined by the downward slope in mouthflow after surpassing maximum flow (Max-F), and the surge in oropharyngeal pressure before initial contact between the tongue tip and alveolar ridge. Timestamps for the pre-closure phase included: onset-v, onset-/r/, max-F, end-gest-/r/.

Figure 1. Annotations on the filtered aerodynamic signal. The bold-dashed lines represent the timestamps for the pre-closure phase of the apical trill and preceding vowel. (a) marks the onset of the vowel (onset-v), (b) marks the onset of the rhotic

(onset-/r/), (c) represents maximum mouthflow (max-F), and (d) marks the end of the rhotic onset (beginning of closure-phase).

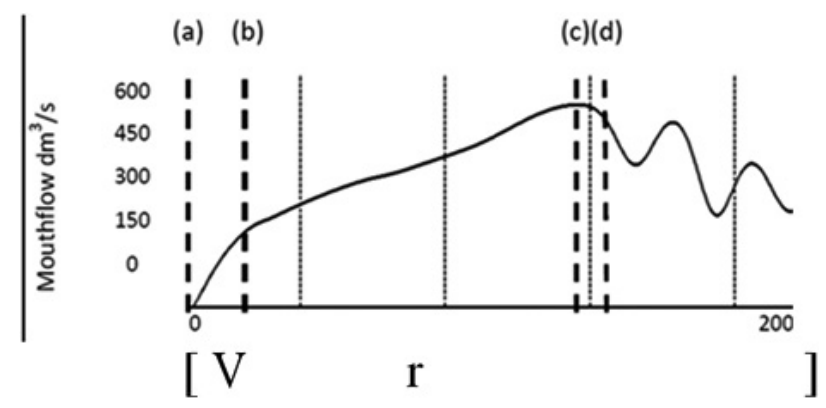

\subsection{Statistical analyses}

Linear mixed effects models were employed to analyze the effects of phonetic environment on the aerodynamic characteristics of apical taps and trills using the lme4 package in R (Bates, Maechler, Bolker, \& Walker, 2015). Mixed effects models were preferred over a repeated measures multi-level ANOVA design in order to avoid potential inflation of the F-ratio which results from violations of the sphericity assumption. Continuous variables were divided into two domains: aerodynamic and temporal. An addition- al variable, CONT P, reflecting the quantity of contact points for trills was also modeled. The aerodynamic variables included (1) peak mouthflow (Max_F), and (2) average mouthflow (Avg_F). The temporal variables were (1) the duration from the onset of phonation to the activation of the tongue tip gesture for the rhotic (Duration_v_rhotic onset), (2) the duration of the rhotic onset gesture (and pressure buildup; Duration_r_onset), (3) the duration of the entire vowel and rhotic onset sequence (Duration_sequence), and (4) the degree of overlap (i.e., coarticulation) between the vowel and rhotic onset (Overlap). These variables were tested as functions of predictors which reference tongue posture settings for the preceding vowel (Anteriority [ANT] and Height [HGHT]), the constriction degree (CONS DEG) and constriction location (CONS LOC) of the following consonant, as well as the rhotic gesture itself ([SEG] Segment).

Continuous variables were subjected to logit transformations in order to ensure normal distribution of the response variables, and qq plots for the residuals were used as well to evaluate normal distribution. In all cases, models were tested for main effects and all interactions. To account for differences in speech rate and individual variation, repetition and speaker were modeled as random effects. Both random intercepts by subject as well as random by-subject slopes were included. Although variation in the continuous variables based on the sex of the speaker is possible, sex was left unspecified in the models since it is impossible to tease apart effects based on sex from speaker variation with only two subjects. Maximum likelihood chi-squared tests based on the deviance statistics were performed in order to determine significance. For post hoc comparisons, significance was determined using the Tukey adjusted contrast using the multcomp package in R (Hothorn, Bretz, \& Westfall, 2008), which is an appropriate tool for post hoc analysis for mixed models.

Variance inflation factors (VIF) were obtained using the Car package in R (Fox \& Weisberg, 2011) for potentially overlapping predictors before analyses in order to ensure no perfect collinearity existed in the model which would affect the results (Fox, 2008). For all factors, the VIF was $(<5)$, meaning collinearity is not detrimentally present in the models.

An outline of the dependent variables, predictors and random effects used for these models appears in Table 1.

Finally, a Bayesian logit regression programmed with non-informative priors (13,000 iterations of the Markov chain Monte Carlo algorithm with a burn-in of 3,000, and thinning of 10) was used to examine the distribution of trill production as a function of the continuous temporal and aerodynamic variables outlined above using the MCMCglmm package in R (Hadfield, 2010). A Bayesian logit regression was chosen over maximum likelihood models (generalized linear models, for example) due to the fact that generalized linear models may not perform under separation, and may give noisy answers for small data sets (Gelman, 2008). Additionally it has been shown that nonbayesian machine learning algorithms underestimate uncertainty in predictions (Gelman, in press). To account for 
Table 1. Summary of fixed effects, variables and random effects.

\begin{tabular}{|c|c|}
\hline Fixed effects & Levels \\
\hline Anteriority (ANT) & Front, mid, back \\
\hline Height (HGHT) & High, mid, low \\
\hline $\begin{array}{l}\text { Constriction Degree } \\
\text { (CONS_DEG) }\end{array}$ & Wide, narrow \\
\hline $\begin{array}{l}\text { Constriction Location } \\
\text { (CONS_LOC) }\end{array}$ & Lips, tongue tip, tongue body \\
\hline Segment (SEG) & Tap, trill \\
\hline Dependent variables & Descriptions \\
\hline Duration_v_rhotic_onset & $\begin{array}{l}\text { Onset of phonation to onset of } \\
\text { rhotic }\end{array}$ \\
\hline Duration_r_onset & $\begin{array}{l}\text { Onset of tongue tip to first } \\
\text { contact }\end{array}$ \\
\hline Duration_sequence & $\begin{array}{l}\text { Onset of phonation to onset of } \\
\text { contact plateau }\end{array}$ \\
\hline Overlap & $\begin{array}{l}\text { Duration of the (entire) vowel } \\
+ \text { the duration of the rhotic } \\
\text { onset divided by the duration } \\
\text { of the vowel and rhotic onset } \\
\text { sequence }\end{array}$ \\
\hline Max_F & Peak mouthflow \\
\hline Avg_F & $\begin{array}{l}\text { Sum of mouthflow values } \\
\text { divided by number of temporal } \\
\text { landmarks }\end{array}$ \\
\hline Contact points (CONT_P) & Number of contact points \\
\hline \multicolumn{2}{|l|}{ Random effects } \\
\hline Speaker & 1,2 \\
\hline Repetitions & $1,2,3$ \\
\hline
\end{tabular}

the variation between speakers, and different repetitions by the same speaker, repetition was nested within speaker and were then modeled as random effects. A Markov chain Monte Carlo algorithm was used to derive posterior distributions for model parameters. Goodness of fit for the model was assessed using the deviance information criteria (DIC), which provides a hierarchical modeling generalization of the AIC (Akaike information criterion) and BIC (Bayesian information criterion). As with the AIC and BIC, a lower DIC indicates better model fit.

\subsection{Results}

\subsubsection{Temporal parameters}

Tongue anteriority for the preceding vowel has a main effect on the latency from the initiation of phonation to the onset of the tongue tip gesture $\left(\chi^{2}[1, N=865]=864\right.$, $p<.001)$, as does tongue height $\left(\chi^{2}[1, N=865]=864\right.$, $p<.0001)$, but not their interaction $\left(\chi^{2}[1, N=865]=864\right.$, $p=1.0)$. Pooled means are plotted by factor in Figure 2 .
Figure 2. Pooled mean durations by factor from the onset of phonation to the onset of the tongue tip gesture for the rhotic.
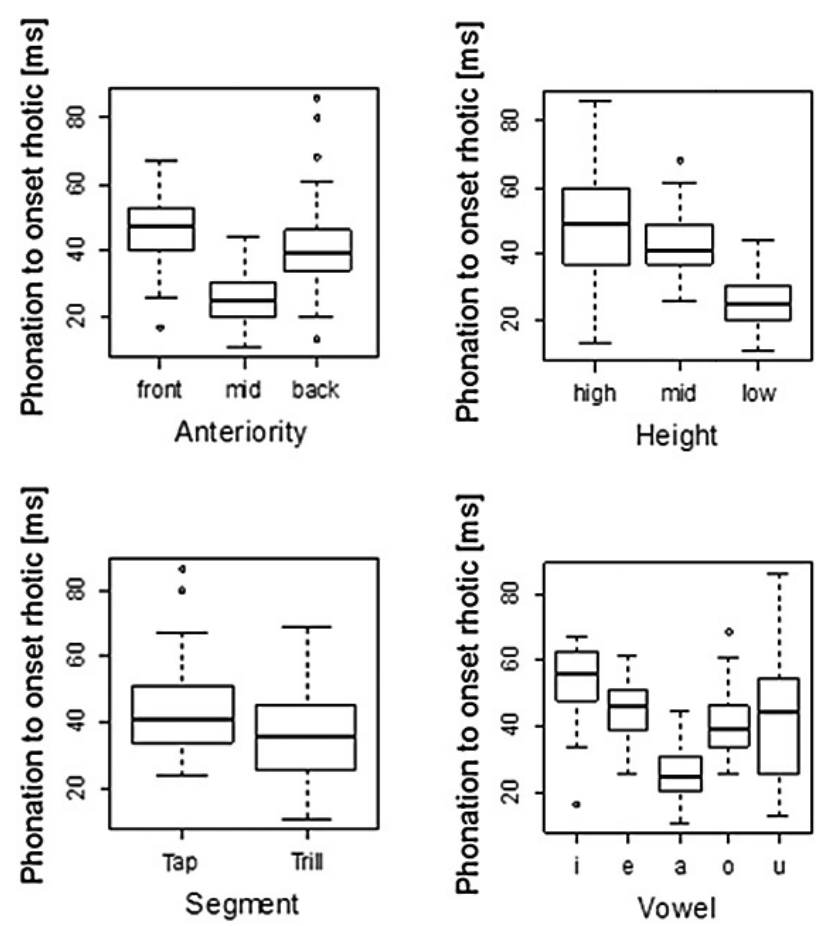

As regards anteriority, the mid vowel (Table 2) showed the shortest period between phonation and the onset of the tap for both speakers (Speaker 1: $M=36.2$ $\mathrm{ms}, \pm 8.1 \mathrm{~ms}$; Speaker 2: $M=29.8 \mathrm{~ms}, \pm 7.3 \mathrm{~ms})$, a trend which was obtained for trills as well (Speaker 1: $M=24.6$ $\mathrm{ms}, \pm 7.6$; Speaker 2: $M=28.4 \mathrm{~ms}, \pm 7.1)$. With regard to height, high vowels had the longest duration between the onset of phonation and the onset of tongue tip ascension in taps (Speaker 1: $M=57.5 \mathrm{~ms}, \pm 20.4 \mathrm{~ms}$; Speaker 2: $M$ $=51.8 \mathrm{~ms}, \pm 9.6)$, though in trills the maxima between high and mid vowels fluctuated, mid vowels showing a longer duration for Speaker 1.

There was no main effect for the tap/trill contrast $\left(\chi^{2}[1, N=865]=864, p=.35\right)$ on the vowel to rhotic onset measure, though a significant three-way interaction between segment, height and anteriority was found $\left(\chi^{2}[1\right.$, $N=865]=864, p=.007)$. A summary of the means and standard deviations by speaker appears in Table 2 .

Neither constriction degree nor constriction location had any effect on the temporal distance between the two landmarks (CONS_DEG: $\chi^{2}[1, N=865]=864, p=1.0$; CONS_LOC: $\left.\chi^{2}[1, N=865]=864, p=1.0\right)$, nor interactions with other predictors ( $p=1.0$ for all contrasts).

As regards the duration of the tongue tip gesture leading up to the first alveolar contact point (Figure 3), no main effect for either height $\left(\chi^{2}[1, N=865]=864, p=\right.$ $1.0)$ or anteriority $\left(\chi^{2}[1, N=865]=864, p=.33\right)$ was found, though their interaction was significant $\left(\chi^{2}[1, N=\right.$ $865]=864, p<.001)$. Pooled means are plotted by factor in Figure 3. 
Table 2. Duration from onset of phonation to rhotic onset (ms) by factor. $\mathrm{ANT}=$ anteriority; HGHT $=$ height.

\begin{tabular}{|c|c|c|c|c|c|}
\hline \multirow[b]{2}{*}{ Segment } & \multirow[b]{2}{*}{ Speaker } & \multirow[b]{2}{*}{ Factor } & \multirow[b]{2}{*}{ Level } & \multicolumn{2}{|c|}{ Duration_v_onset_r } \\
\hline & & & & Mean & $S D$ \\
\hline \multirow[t]{12}{*}{ Tap } & 1 & ANT & front & 48.6 & 9.8 \\
\hline & & & mid & 36.2 & 8.1 \\
\hline & & & back & 50.8 & 22.0 \\
\hline & & HGHT & high & 57.5 & 20.4 \\
\hline & & & mid & 41.9 & 5.0 \\
\hline & & & low & 36.2 & 8.1 \\
\hline & 2 & ANT & front & 47.9 & 10.7 \\
\hline & & & mid & 29.8 & 7.3 \\
\hline & & & back & 40.4 & 12.3 \\
\hline & & HGHT & high & 51.8 & 9.6 \\
\hline & & & mid & 36.5 & 8.5 \\
\hline & & & low & 29.8 & 7.3 \\
\hline \multirow[t]{12}{*}{ Trill } & 1 & ANT & front & 46.6 & 10.3 \\
\hline & & & mid & 24.6 & 7.6 \\
\hline & & & back & 40.7 & 9.8 \\
\hline & & HGHT & high & 42.6 & 16.5 \\
\hline & & & mid & 43.6 & 9.0 \\
\hline & & & low & 24.6 & 7.6 \\
\hline & 2 & ANT & front & 42.4 & 14.3 \\
\hline & & & mid & 28.4 & 7.1 \\
\hline & & & back & 33.2 & 11.4 \\
\hline & & HGHT & high & 43.4 & 13.1 \\
\hline & & & mid & 39.5 & 10.3 \\
\hline & & & low & 28.4 & 7.1 \\
\hline
\end{tabular}

Figure 3. Pooled means (ms) for rhotic onset duration plotted by factor.
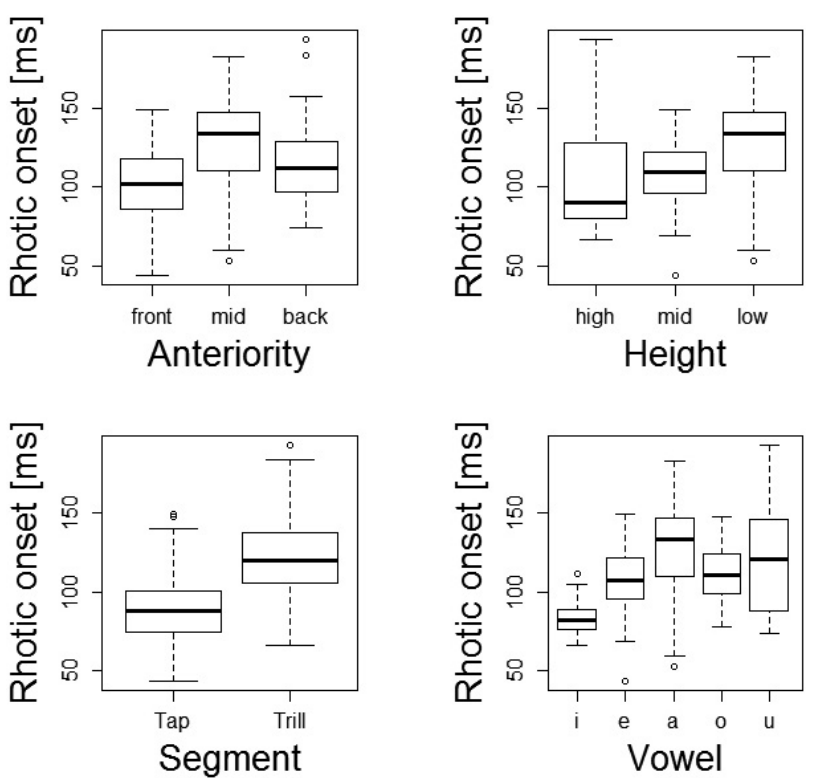

Concerning anteriority (Table 3 ), the tongue tip gesture following a mid vowel had the shortest duration in taps for Speaker $1(M=72.4 \mathrm{~ms}, \pm 21.8 \mathrm{~ms})$, but the longest for trills $(M=136.9 \mathrm{~ms}, \pm 23.2 \mathrm{~ms})$. For Speaker 2 , the rhotic onset gesture following back vowels showed the longest duration in both taps $(M=101.3 \mathrm{~ms}, \pm 25.5$ $\mathrm{ms})$ and trills $(M=141.1 \mathrm{~ms}, \pm 28.7)$. As for height, the tongue tip gesture for the rhotic following the low vowel had the shortest latencies in taps for both speakers (Speaker 1: $M=72.4 \mathrm{~ms}, \pm 21.8 \mathrm{~ms}$; Speaker 2: $M=85.0$ $\mathrm{ms}, \pm 16.0 \mathrm{~ms})$, yet the longest duration for both speakers in trills (Speaker 1: $M=136.9 \mathrm{~ms}, \pm 23.2 \mathrm{~ms}$; Speaker 2: $M=126.0 \mathrm{~ms}, \pm 15.9 \mathrm{~ms}$ ). A significant three-way interaction was found between anteriority, height and segment $\left(\chi^{2}[1, N=865]=864, p<.001\right)$. A summary of the means and standard deviations by speaker appears in Table 3.

Again, no main effects or interactions were found for the constriction degree or constriction location of the following consonants ( $p>.05$ for all contrasts).

Table 3. Duration for rhotic onset (ms). ANT = anteriority; HGHT $=$ height.

\begin{tabular}{|c|c|c|c|c|c|}
\hline \multirow[b]{2}{*}{ Segment } & \multirow[b]{2}{*}{ Speaker } & \multirow[b]{2}{*}{ Factor } & \multirow[b]{2}{*}{ Level } & \multicolumn{2}{|c|}{ Duration_r_onset } \\
\hline & & & & Mean & $S D$ \\
\hline \multirow[t]{12}{*}{ Tap } & 1 & ANT & front & 95.2 & 32.4 \\
\hline & & & mid & 72.4 & 21.8 \\
\hline & & & back & 96.9 & 20.6 \\
\hline & & HGHT & high & 87.6 & 10.9 \\
\hline & & & mid & 106.1 & 34.0 \\
\hline & & & low & 72.4 & 21.8 \\
\hline & 2 & ANT & front & 80.9 & 7.5 \\
\hline & & & mid & 85.0 & 16.0 \\
\hline & & & back & 101.3 & 25.5 \\
\hline & & HGHT & high & 87.13 & 17.6 \\
\hline & & & mid & 95.0 & 24.4 \\
\hline & & & low & 85.0 & 16.0 \\
\hline \multirow[t]{12}{*}{ Trill } & 1 & ANT & front & 106.2 & 19.4 \\
\hline & & & mid & 136.9 & 23.2 \\
\hline & & & back & 116.3 & 19.2 \\
\hline & & HGHT & high & 116.9 & 34.6 \\
\hline & & & mid & 110.6 & 16.0 \\
\hline & & & low & 136.9 & 23.2 \\
\hline & 2 & ANT & front & 104.9 & 22.9 \\
\hline & & & mid & 126.0 & 15.9 \\
\hline & & & back & 141.1 & 28.7 \\
\hline & & HGHT & high & 93.0 & 18.7 \\
\hline & & & mid & 119.3 & 22.3 \\
\hline & & & low & 126.0 & 15.9 \\
\hline
\end{tabular}


With regard to the latency for the entire vowel + rhotic onset sequence (Duration_sequence), the only main effect was found for the tap/trill contrast $\left(\chi^{2}[1, N=865]=\right.$ $864, p<.001)$. Neither the anteriority $\left(\chi^{2}[1, N=865]=\right.$ $864, p=.81)$ nor the height $\left(\chi^{2}[1, N=865]=864, p=1.0\right)$ of the preceding vowel showed any effect for either subject, nor did their interaction with the tap/trill contrast $\left(\chi^{2}[1, N=865]=864, p=1.0\right)$. Pooled means are illustrated by factor in Figure 4.

Figure 4. Duration of entire vowel and rhotic onset sequence.
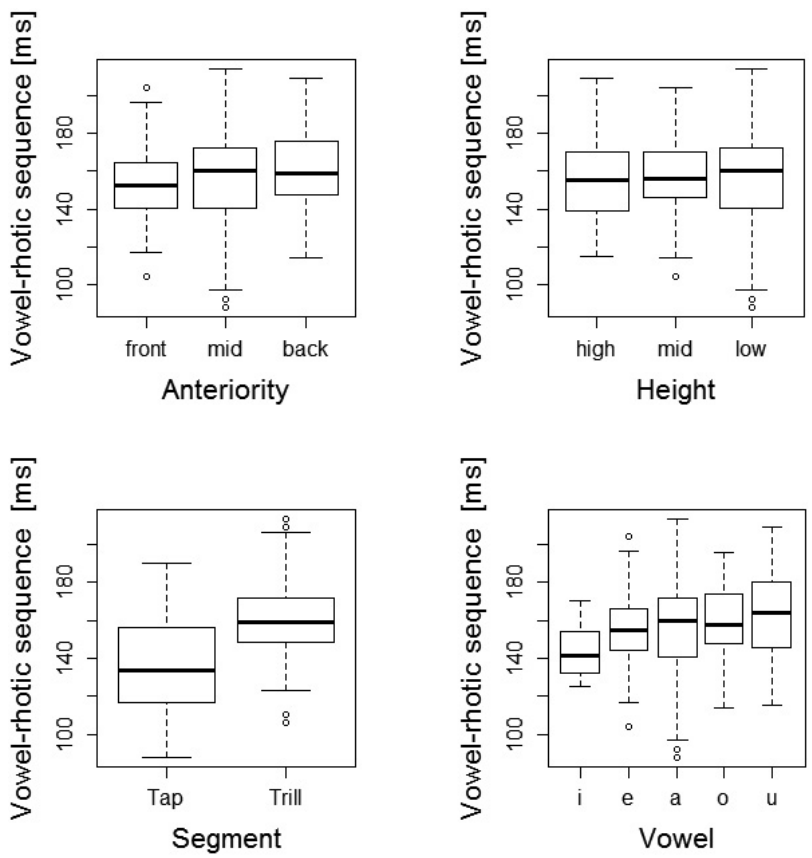

Pooled means show a $31.3 \mathrm{~ms}$ increase in the duration of the vowel + rhotic onset sequence in trills $(M=164.8$ $\mathrm{ms}, \pm 13.8)$ over taps $(M=133.4 \mathrm{~ms}, \pm 19.3$ ) (Tukey HSD: $p<.001)$. For Speaker 1, the mean duration for sequences with taps was $139 \mathrm{~ms}( \pm 26 \mathrm{~ms})$, while sequences with trills showed a mean duration of $161 \mathrm{~ms}( \pm 23$ $\mathrm{ms}$ ), though this difference is not significant (Tukey HSD: $p=.06)$. For Speaker 2, mean duration in sequences with taps was $128 \mathrm{~ms}( \pm 15 \mathrm{~ms})$, while mean duration of the sequences which contained trills was significantly longer $(M=169 \mathrm{~ms}, \pm 21 \mathrm{~ms}$, Tukey HSD: $p=.002)$.

Concerning the effects of anteriority of the preceding vowel on the duration of the sequence (Table 4), the mid vowel + rhotic onset sequence in taps was shortest for both subjects (Speaker 1: $M=105.6 \mathrm{~ms}, \pm 20.5 \mathrm{~ms}$; Speaker 2: $M=114.8 \mathrm{~ms}, \pm 20.3 \mathrm{~ms}$ ). In trills, however, the mid-vowel + rhotic onset sequence for Speaker 1 showed the longest duration $(M=164.4 \mathrm{~ms}, \pm 23.7 \mathrm{~ms})$. For Speaker 2 the back vowel + rhotic onset sequence showed the highest value in trills $(M=176.1 \mathrm{~ms}, \pm 23.4$ $\mathrm{ms})$. For both speakers, the front-vowel + rhotic onset sequences had the shortest duration in trills (Speaker 1: $M=$ $156.7 \mathrm{~ms}$, $\pm 17.6 \mathrm{~ms}$; Speaker 2: $M=154.9 \mathrm{~ms}$, \pm
Table 4. Duration of vowel + rhotic onset sequence (ms). ANT $=$ anteriority; $\mathrm{HGHT}=$ height.

\begin{tabular}{|c|c|c|c|c|c|}
\hline \multirow[b]{2}{*}{ Segment } & \multirow[b]{2}{*}{ Speaker } & \multirow[b]{2}{*}{ Factor } & \multirow[b]{2}{*}{ Level } & \multicolumn{2}{|c|}{ Duration_sequence } \\
\hline & & & & Mean & $S D$ \\
\hline \multirow[t]{12}{*}{ Tap } & 1 & ANT & front & 156.6 & 20.1 \\
\hline & & & mid & 105.6 & 20.5 \\
\hline & & & back & 154.4 & 21.1 \\
\hline & & HGHT & high & 147.9 & 20.6 \\
\hline & & & mid & 163.1 & 17.1 \\
\hline & & & low & 105.6 & 20.5 \\
\hline & 2 & ANT & front & 127.5 & 15.7 \\
\hline & & & mid & 114.8 & 20.3 \\
\hline & & & back & 141.6 & 24.2 \\
\hline & & HGHT & high & 138.9 & 18.7 \\
\hline & & & mid & 130.3 & 23.5 \\
\hline & & & low & 114.8 & 20.3 \\
\hline \multirow[t]{12}{*}{ Trill } & 1 & ANT & front & 156.7 & 17.6 \\
\hline & & & mid & 164.4 & 23.7 \\
\hline & & & back & 160.4 & 18.2 \\
\hline & & HGHT & high & 162.8 & 19.0 \\
\hline & & & mid & 157.9 & 17.7 \\
\hline & & & low & 164.4 & 23.7 \\
\hline & 2 & ANT & front & 154.9 & 8.4 \\
\hline & & & mid & 155.2 & 13.8 \\
\hline & & & back & 176.1 & 23.4 \\
\hline & & HGHT & high & 206.4 & 39.4 \\
\hline & & & mid & 163.3 & 17.1 \\
\hline & & & low & 155.2 & 13.8 \\
\hline
\end{tabular}

$8.4 \mathrm{~ms}$ ). A summary of the means (ms) and standard deviations for the vowel + rhotic onset sequence by speaker appears in Table 4.

Once more, neither constriction degree $\chi^{2}[1, N=865]$ $=864, p=1.0)$ nor constriction location $\left(\chi^{2}[1, N=865]=\right.$ $864, p=1.0)$ had any effect on the test variable.

As for the overlap between the preceding vowel and tongue tip gesture for the rhotic onset (Figure 5), anteriority $\left(\chi^{2}[1, N=865]=864, p=.02\right)$, height $\left(\chi^{2}[1, N=865]\right.$ $=864, p<.001)$ and segment $\left(\chi^{2}[1, N=865]=864, p<\right.$ $.001)$ all showed significant main effects for both subjects, as well as a three-way interaction $\left(\chi^{2}[1, N=865]=\right.$ $864, p=.002)$. A plot of the pooled means by factor appears in Figure 5.

Generally, trills showed more overlap than taps (Tukey HSD: $p<.001$; see Table 5). With regard to vowel height, the low vowel exhibited the most gestural overlap for both speakers and segments (Taps: Speaker 1: $M=$ $0.68, \pm 0.07$; Speaker 2: $M=0.74, \pm 0.04$; Trills: Speaker 
Figure 5. Overlap patterns plotted by factor.
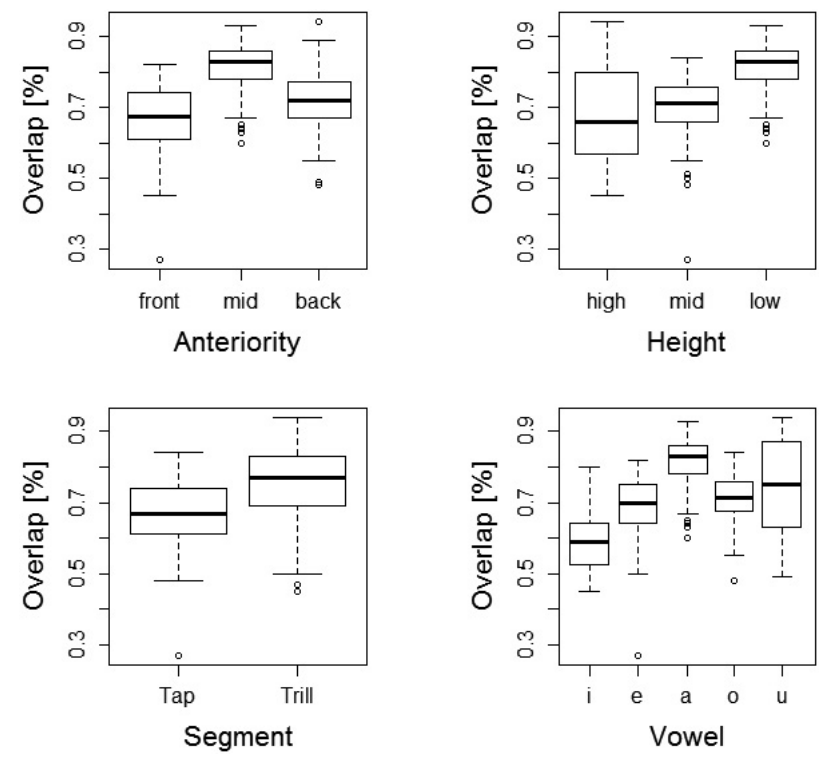

$1: M=0.83, \pm 0.06$; Speaker $2: M=0.81, \pm 0.04)$. Conversely, high vowels showed the least amount of overlap, the only exception being for trills by Speaker 2 (high vowel: $M=0.71, \pm 0.16$; mid vowel: $M=0.70, \pm 0.06$ ). However, between the high vowels, [i] showed significantly less overlap than [u] (Tukey HSD: $p<.001$ ) for both speakers, suggesting it is not merely height, but rather height combined with fronting that which impedes overlap between the vowel and rhotic onset.

With regard to anteriority, mid vowels, followed by back vowels, showed the most gestural overlap, while front vowels exhibited less gestural overlap for both segments and speakers.

A summary of the means and standard deviations for the overlap patterns by speaker appears in Table 5 .

No main effects were found for the constriction degree and constriction location of the following consonants.

A summary of the main effects for all fixed effects appears in Table 6.

\subsubsection{Aerodynamic parameters}

Peak mouthflow proved to be a function of tongue posture in both the vertical and horizontal planes. Strong main effects were found for anteriority $\left(\chi^{2}[1, N=865]=\right.$ $864, p<.001)$, height $\left(\chi^{2}[1, N=865]=864, p<.001\right)$, and segment $\left(\chi^{2}[1, N=865]=864, p<.001\right)$. Interestingly, no interaction between these fixed effects was found $\left(\chi^{2}[1, N=865]=864, p=.35\right)$. In line with previous models, neither the constriction degree $\left(\chi^{2}[1, N=\right.$ $865]=864, p=1.0)$ nor the constriction location $\left(\chi^{2}[1, N\right.$ $=865]=864, p=1.0$ ) had a main effect on peak flow values. Pooled means for both speakers are plotted by relevant factor in Figure 6.
Table 5. Summary means and standard deviations for overlap by speaker. ANT = anteriority; $\mathrm{HGHT}=$ height.

\begin{tabular}{|c|c|c|c|c|c|}
\hline \multirow[b]{2}{*}{ Segment } & \multirow[b]{2}{*}{ Speaker } & \multirow[b]{2}{*}{ Factor } & \multirow[b]{2}{*}{ Level } & \multicolumn{2}{|c|}{ Overlap } \\
\hline & & & & Mean & $S D$ \\
\hline \multirow[t]{12}{*}{ Tap } & 1 & ANT & front & 0.61 & 0.16 \\
\hline & & & mid & 0.68 & 0.07 \\
\hline & & & back & 0.63 & 0.13 \\
\hline & & HGHT & high & 0.60 & 0.10 \\
\hline & & & mid & 0.65 & 0.18 \\
\hline & & & low & 0.68 & 0.07 \\
\hline & 2 & ANT & front & 0.64 & 0.06 \\
\hline & & & mid & 0.74 & 0.04 \\
\hline & & & back & 0.71 & 0.09 \\
\hline & & HGHT & high & 0.63 & 0.06 \\
\hline & & & mid & 0.72 & 0.07 \\
\hline & & & low & 0.74 & 0.04 \\
\hline \multirow[t]{12}{*}{ Trill } & 1 & ANT & front & 0.68 & 0.09 \\
\hline & & & mid & 0.83 & 0.06 \\
\hline & & & back & 0.72 & 0.07 \\
\hline & & HGHT & high & 0.71 & 0.16 \\
\hline & & & mid & 0.70 & 0.06 \\
\hline & & & low & 0.83 & 0.06 \\
\hline & 2 & ANT & front & 0.68 & 0.14 \\
\hline & & & mid & 0.81 & 0.04 \\
\hline & & & back & 0.80 & 0.07 \\
\hline & & HGHT & high & 0.61 & 0.10 \\
\hline & & & mid & 0.73 & 0.10 \\
\hline & & & low & 0.81 & 0.04 \\
\hline
\end{tabular}

Table 6. Main effects by variable (rows) and predictors (columns). Shaded cells represent interactions between predictors. $\mathrm{v} r \mathrm{r}$ onset $=$ duration from onset of phonation to rhotic onset; $r$ onset $=$ duration for rhotic onset; sequence $=$ duration of vowel + rhotic onset sequence. $\mathrm{ANT}=$ anteriority; HGHT $=$ height; $\mathrm{SEG}=$ segment; CONS_DEG $=$ constriction degree; CONS LOC $=$ constriction location.

\begin{tabular}{lccccc}
\hline Duration & ANT & HGHT & SEG & CONS_DEG CONS_LOC \\
\hline v_r_onset & $* * *$ & $* * *$ & $n s$ & $n s$ & $n s$ \\
\hline r_onset & $n s$ & $n s$ & $* * *$ & $n s$ & $n s$ \\
\hline sequence & $n s$ & $n s$ & $* *$ & $n s$ & $n s$ \\
\hline Overlap & $* *$ & $* * *$ & $* * *$ & $n s$ & $n s$ \\
\hline
\end{tabular}

Significance codes: ‘***’ .001/“**’ .01/“*’.05/ 'ns'.1

Peak mouthflow was higher in trills than taps for both speakers (Table 7). As regards anteriority, the mid vowel showed the highest mouthflow values (Taps: Speaker 1: $M=0.453 \mathrm{dm}^{3} / \mathrm{s}, \pm 0.070 \mathrm{dm}^{3} / \mathrm{s}$; Speaker $2: M=0.310$ 
Figure 6. Mean peak mouthflow values by factor.
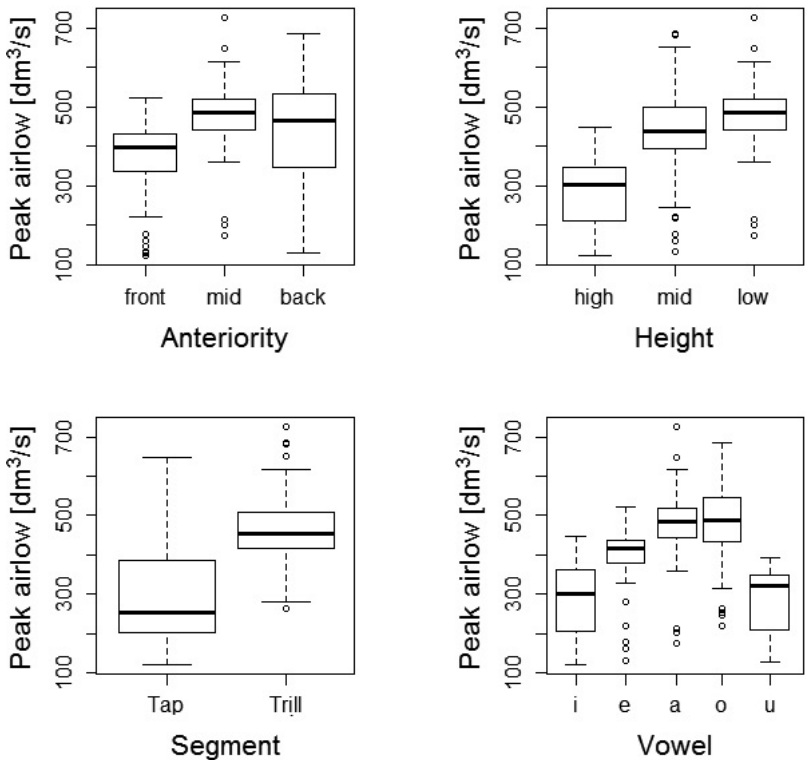

$\mathrm{dm}^{3} / \mathrm{s}, \pm 0.230 \mathrm{dm}^{3} / \mathrm{s}$; Trills: Speaker 1: $M=0.481 \mathrm{dm}^{3} / \mathrm{s}$, $\pm 0.050 \mathrm{dm}^{3} / \mathrm{s} ;$ Speaker 2: $M=0.442 \mathrm{dm}^{3} / \mathrm{s}, \pm 0.090$ $\mathrm{dm}^{3} / \mathrm{s}$ ), except for Speaker 2 in trills, where the back vowels showed a slightly higher mean than the mid vowel $\left(0.483 \mathrm{dm}^{3} / \mathrm{s}\right.$ for back vowels as opposed to $0.481 \mathrm{dm}^{3} / \mathrm{s}$ for the mid vowel). Front vowels showed the lowest mean peak mouthflow values for both speakers and rhotics (Taps: Speaker 1: $M=0.338 \mathrm{dm}^{3} / \mathrm{s}, \pm 0.060$; Speaker 2: $M=0.156 \mathrm{dm}^{3} / \mathrm{s}, \pm 0.030 \mathrm{dm}^{3} / \mathrm{s}$; Trills: Speaker $1: M=$ $0.409 \mathrm{dm}^{3} / \mathrm{s}, \pm 0.050 \mathrm{dm}^{3} / \mathrm{s}$; Speaker $2: M=0.417 \mathrm{dm}^{3} / \mathrm{s}$, $\pm 0.100 \mathrm{dm}^{3} / \mathrm{s}$ ). Post hoc Tukey HSD tests are significant for all contrasts based on anteriority (Speaker 1: frontback: $p<.001$; mid-back: $p<.001$; mid-front: $p<.001$; Speaker 2: front-back: $p<.001$; mid-back: $p<.001$; midfront: $p<.001)$.

As regards the effects of tongue height on mouth flow, there is an inverse relationship between height and flow such that a lower posture yields higher peak flow values (Table 7). High vowels showed the lowest mean peak flow values for both speakers and rhotics (Taps: Speaker 1: $M=0.284 \mathrm{dm}^{3} / \mathrm{s}, \pm 0.050 \mathrm{dm}^{3} / \mathrm{s}$; Speaker 2: $M=0.158 \mathrm{dm}^{3} / \mathrm{s}, \pm 0.040 \mathrm{dm}^{3} / \mathrm{s}$; Trills: Speaker 1: $M=0.359 \mathrm{dm}^{3} / \mathrm{s}, \pm 0.050 \mathrm{dm}^{3} / \mathrm{s}$; Speaker 2: $M=0.304 \mathrm{dm}^{3} / \mathrm{s}, \pm 0.090 \mathrm{dm}^{3} / \mathrm{s}$ ), followed by mid vowels (Taps: Speaker 1: $M=0.439 \mathrm{dm}^{3} / \mathrm{s}, \pm 0.070$ $\mathrm{dm}^{3} / \mathrm{s}$; Speaker 2: $M=0.209 \mathrm{dm}^{3} / \mathrm{s}, \pm 0.050 \mathrm{dm}^{3} / \mathrm{s}$; Trills: Speaker 1: $M=0.464 \mathrm{dm}^{3} / \mathrm{s}, \pm 0.080 \mathrm{dm}^{3} / \mathrm{s}$; Speaker 2: $M=0.442 \mathrm{dm}^{3} / \mathrm{s}, \pm 0.090 \mathrm{dm}^{3} / \mathrm{s}$ ). The low vowel showed the highest peak flow values for both speakers and rhotics (Taps: Speaker 1: $M=0.453 \mathrm{dm}^{3} / \mathrm{s}$, $\pm 0.070 \mathrm{dm}^{3} / \mathrm{s} ;$ Speaker 2: $M=0.310 \mathrm{dm}^{3} / \mathrm{s}, \pm 0.230$ $\mathrm{dm}^{3} / \mathrm{s}$; Trills: Speaker 1: $M=0.481 \mathrm{dm}^{3} / \mathrm{s}, \pm 0.050$ $\mathrm{dm}^{3} / \mathrm{s}$; Speaker 2: $M=0.507 \mathrm{dm}^{3} / \mathrm{s}, \pm 0.080 \mathrm{dm}^{3} / \mathrm{s}$ ). Post hoc Tukey HSD tests show significant results for all contrasts based on height for both speakers (Speaker
1: high-mid, $p<.001$; mid-low, $p<.001$; high-low, $p<$ .001 ; Speaker 2: high-mid, $p<.001$; mid-low, $p<.001$; high-low, $p<.001$ ).

As for the tap/trill contrast, pooled means show a $0.131 \mathrm{dm}^{3} / \mathrm{s}$ increase in peak flow for trills $(M=0.440$ $\left.\mathrm{dm}^{3} / \mathrm{s}, \pm 0.060 \mathrm{dm}^{3} / \mathrm{s}\right)$ over taps $\left(M=0.309 \mathrm{dm}^{3} / \mathrm{s}\right.$, $\pm 0.110 \mathrm{dm}^{3} / \mathrm{s}$ ) across all vowel categories. For Speaker 2 , the difference in peak flow between taps and trills $\left(0.210 \mathrm{dm}^{3} / \mathrm{s}\right)$ was higher than for Speaker $1(0.054$ $\mathrm{dm}^{3} / \mathrm{s}$ ), though the results of post hoc Tukey HSD tests show significance for both speakers (Tukey HSD: $p<.001$ for Speakers 1 and 2).

A summary of the means and standard deviations for peak mouthflow by speaker appears in Table 8 .

Average mouthflow leading up to the first contact point with the alveolar region was also found to be influenced by tongue posture and the tap/trill contrast. Specifically, highfront vowels showed slower flow (and faster $\mathrm{P}_{\mathrm{o}}$ buildup)

Table 7. Summary of means and standard deviations for peak mouthflow $($ Max F $)$ by speaker. ANT = anteriority; HGHT = height.

\begin{tabular}{|c|c|c|c|c|c|}
\hline \multirow[b]{2}{*}{ Segment } & \multirow[b]{2}{*}{ Speaker } & \multirow[b]{2}{*}{ Factor } & \multirow[b]{2}{*}{ Level } & \multicolumn{2}{|c|}{ Max_F } \\
\hline & & & & Mean & $S D$ \\
\hline \multirow[t]{12}{*}{ Tap } & 1 & ANT & front & 0.338 & 0.060 \\
\hline & & & mid & 0.453 & 0.067 \\
\hline & & & back & 0.384 & 0.126 \\
\hline & & HGHT & high & 0.284 & 0.048 \\
\hline & & & mid & 0.439 & 0.067 \\
\hline & & & low & 0.453 & 0.067 \\
\hline & 2 & ANT & front & 0.156 & 0.032 \\
\hline & & & mid & 0.310 & 0.227 \\
\hline & & & back & 0.211 & 0.047 \\
\hline & & HGHT & high & 0.158 & 0.035 \\
\hline & & & mid & 0.209 & 0.048 \\
\hline & & & low & 0.310 & 0.227 \\
\hline \multirow[t]{12}{*}{ Trill } & 1 & ANT & front & 0.409 & 0.045 \\
\hline & & & mid & 0.481 & 0.052 \\
\hline & & & back & 0.483 & 0.096 \\
\hline & & HGHT & high & 0.359 & 0.051 \\
\hline & & & mid & 0.464 & 0.080 \\
\hline & & & low & 0.481 & 0.052 \\
\hline & 2 & ANT & front & 0.417 & 0.104 \\
\hline & & & mid & 0.507 & 0.078 \\
\hline & & & back & 0.436 & 0.094 \\
\hline & & HGHT & high & 0.304 & 0.054 \\
\hline & & & mid & 0.442 & 0.087 \\
\hline & & & low & 0.507 & 0.078 \\
\hline
\end{tabular}


leading up to the first contact point than mid, low and back vowels, presumably due to greater impedance in the vocal tract during the production of high vowels. A strong main effect on average mouthflow was found based on the anterior/posterior position $\left(\chi^{2}[1, N=865]=864, p<.001\right)$, while a weak effect was found for the tap/trill contrast $\left(\chi^{2}[1, N=865]=864, p=.03\right)$, but only for Speaker 2 . Tongue height showed no main effect on mouthflow leading up to trilling $\left(\chi^{2}[1, N=865]=864, p=1.0\right)$. There was no interaction between these fixed effects $\left(\chi^{2}[1, N=865]=\right.$ $864, p=.29)$. No effects were found for the constriction degree $\left(\chi^{2}[1, N=865]=864, p=1.0\right)$ or the constriction location $\left(\chi^{2}[1, N=865]=864, p=1.0\right)$ of the following consonant. Data from the models are plotted in Figure 7.

Figure 7. Pooled means of average mouthflow plotted by factor.
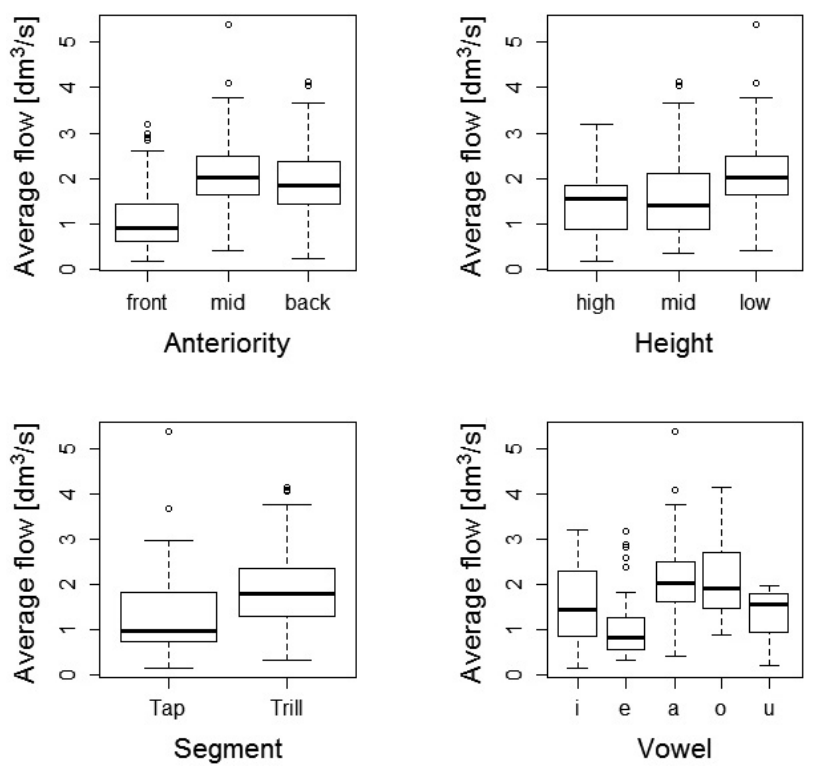

Pooled means show an average flow of $0.129 \mathrm{dm}^{3} / \mathrm{s}$ $\left( \pm 0.068 \mathrm{dm}^{3} / \mathrm{s}\right)$ for taps, while the average flow for trills is slightly higher $\left(M=0.177 \mathrm{dm}^{3} / \mathrm{s}, \pm 0.040 \mathrm{dm}^{3} / \mathrm{s}\right)$. However, across subjects, this trend does not hold. For Speaker 1, average mouthflow values for both taps and trills are only marginally different, taps having higher flow values than trills (Taps: $M=0.190 \mathrm{dm}^{3} / \mathrm{s}, \pm 0.052 \mathrm{dm}^{3} / \mathrm{s}$; Trills: $M=0.184 \mathrm{dm}^{3} / \mathrm{s}, \pm 0.033 \mathrm{dm}^{3} / \mathrm{s}$ ) (Tukey HSD: $p=1.0$, $n s)$. For Speaker 2, there is significantly lower mouthflow in taps $\left(M=0.110 \mathrm{dm}^{3} / \mathrm{s}, \pm 0.035 \mathrm{dm}^{3} / \mathrm{s}\right)$ than in trills $(M$ $=0.170 \mathrm{dm}^{3} / \mathrm{s}, \pm 0.048 \mathrm{dm}^{3} / \mathrm{s}$ ) (Tukey HSD: $p<.01$ ).

As for tongue anteriority (Table 8 ), the mid vowel showed the fastest mean mouthflow for both speakers, the exception being in trills for Speaker 1. In this context, the back vowels showed higher mouthflow than the mid vowel, although this difference was not significant (Tukey HSD: $p=.975$ ). Front vowels consistently showed the lowest mouthflow for both segments and speakers (Tukey HSD: mid-front: $p<.001$; front-back: $p<.001$ ).
With regard to height (Table 8), the low vowel had the fastest mouthflow for both segments and speakers, contrasting with Solé's (2002) findings. The high vowels had the lowest average mouthflow values in all but one context. For Speaker 1, average flow for the high vowels in trills surpassed that of the mid vowel (though still fell short compared to low vowels), rendering a significant difference (Tukey HSD: $p=.02$ ). A summary of the means and standard deviations for mouthflow are listed in Table 8

Table 9 summarizes the results of the aerodynamic variables (rows) for each predictor (columns).

\subsubsection{Contact points}

To examine the effects of the surrounding gestures on the number of contact points for trills, both categorical and continuous predictors were modeled. Across all factors,

Table 8. Average mouthflow (Avg_F) values by factor and speaker. $\mathrm{ANT}=$ anteriority; HGHT $=$ height.

\begin{tabular}{|c|c|c|c|c|c|}
\hline \multirow[b]{2}{*}{ Segment } & \multirow[b]{2}{*}{ Speaker } & \multirow[b]{2}{*}{ Factor } & \multirow[b]{2}{*}{ Level } & \multicolumn{2}{|c|}{ Avg_F } \\
\hline & & & & Mean & $S D$ \\
\hline \multirow[t]{12}{*}{ Tap } & 1 & ANT & front & 0.132 & 0.07 \\
\hline & & & mid & 0.253 & 0.06 \\
\hline & & & back & 0.185 & 0.08 \\
\hline & & HGHT & high & 0.145 & 0.04 \\
\hline & & & mid & 0.172 & 0.10 \\
\hline & & & low & 0.253 & 0.06 \\
\hline & 2 & ANT & front & 0.050 & 0.02 \\
\hline & & & mid & 0.180 & 0.02 \\
\hline & & & back & 0.101 & 0.06 \\
\hline & & HGHT & high & 0.052 & 0.03 \\
\hline & & & mid & 0.102 & 0.06 \\
\hline & & & low & 0.180 & 0.24 \\
\hline \multirow[t]{12}{*}{ Trill } & 1 & ANT & front & 0.124 & 0.07 \\
\hline & & & mid & 0.203 & 0.05 \\
\hline & & & back & 0.213 & 0.07 \\
\hline & & HGHT & high & 0.196 & 0.06 \\
\hline & & & mid & 0.167 & 0.09 \\
\hline & & & low & 0.203 & 0.05 \\
\hline & 2 & ANT & front & 0.148 & 0.13 \\
\hline & & & mid & 0.223 & 0.08 \\
\hline & & & back & 0.160 & 0.04 \\
\hline & & HGHT & high & 0.100 & 0.03 \\
\hline & & & mid & 0.163 & 0.07 \\
\hline & & & low & 0.223 & 0.08 \\
\hline
\end{tabular}


Table 9. Main effects by variable (rows) and predictors (columns). ANT = anteriority; HGHT = height; SEG = segment CONS_DEG $=$ constriction degree; CONS_LOC $=$ constriction location.

\begin{tabular}{lccccc}
\hline & ANT & HGHT & SEG & $\begin{array}{c}\text { CONS } \\
\text { DEG }\end{array}$ & $\begin{array}{c}\text { CONS } \\
\text { LOC }^{-}\end{array}$ \\
\hline Peak Flow & $* * *$ & $* * *$ & $* * *$ & $n s$ & $n s$ \\
Average Flow & $* * *$ & $n s$ & $*$ & $n s$ & $n s$ \\
\hline
\end{tabular}

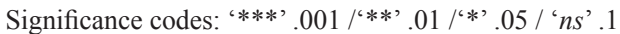

the median number of contact points was three. Minima and maxima reached two and five, respectively. Results of the model show that no factor has any significant effect on the number of contact points for the trill: ANT $\left(\chi^{2}[1, N=\right.$ $191]=190, p=.09)$; HGHT $\left(\chi^{2}[1, N=191]=190, p=\right.$ 48); CONS_DEG $\left(\chi^{2}[1, N=191]=190, p=.78\right)$; CONS LOC $\left(\chi^{2}[1, \bar{N}=191]=190, p=1.0\right) ; \operatorname{Max} F \mathrm{~F}\left(\chi^{2}[1, N=\right.$ $191]=190, p=.33) ; \operatorname{Avg} \mathrm{F}\left(\chi^{2}[1, N=19 \overline{1}]=190, p=\right.$ .74); Duration_r onset $\left(\chi^{2}[1, N=191]=190, p=1.0\right)$; Duration_sequence $\left(\chi^{2}[1, N=191]=190, p=.39\right)$; Overlap $\left(\chi^{2}[1, N=191]=190, p=.43\right)$. These results indicate that although the surrounding gestures may have microeffects on the internal mechanics of trilling, the trill motion itself is highly resilient to environmental influences.

\subsubsection{Bayesian logit regression model to predict tap/trill distribution}

The Bayesian model posits tap/trill variation as a dichotomous outcome model. In the previous sections it has been shown that the tongue posture for the vowel preceding the rhotic affects to a greater or lesser extent the aerodynamic parameters and timing of different stages of the tongue tip's trajectory for the rhotic. So far it has been shown that the lower, and more back, the tongue posture, the higher the peak mouthflow values and the faster mouthflow accelerates going into the contact phase of the trill. At the same time it has been shown that the position in the vertical and horizontal planes affects the timing of the onset of the tongue tip gesture. In this section, a Bayesian model tests whether the distribution of trills can be predicted using these continuous variables. Proper convergence of the parameter estimation and thinning rate were first tested with trace plots, histograms and autocorrelations.

The data show a categorical preference for the apical trill to emerge in certain phonetic environments. There appears to be a preference for trilling in conjunction with [a] $(39.8 \%$ of total $)$ followed by [e] and [o] $(24.6 \%$ and $27.2 \%$ of the cases respectively). Importantly, $91.6 \%$ of all trills emerged with [a], [e], and [o]. The high vowels [i] and $[\mathrm{u}]$ on the other hand show a discernible preference for the tap. A summary of the number of trilled tokens by vocalic and consonantal contexts appears in Table 10.

Not immediately obvious from the data is the highly individual nature of the tap/trill contrast in syllable-final
Table 10. Number of trilled tokens by context.

\begin{tabular}{lrrrrrrr}
\hline & r.p & r.b & r.t & r.d & r.k & r.g & Total \\
\hline $\mathrm{i}$ & 0 & 0 & 6 & 0 & 0 & 1 & 7 \\
$\mathrm{e}$ & 11 & 6 & 14 & 7 & 6 & 3 & 47 \\
$\mathrm{a}$ & 14 & 12 & 13 & 9 & 14 & 14 & 76 \\
$\mathrm{o}$ & 11 & 9 & 5 & 4 & 13 & 10 & 52 \\
$\mathrm{u}$ & 3 & 3 & 2 & 0 & 0 & 1 & 9 \\
\hline Total & 39 & 30 & 40 & 20 & 33 & 29 & 191 \\
\hline
\end{tabular}

position. Of the 191 total trilled tokens, only 17 were produced by speaker 1 , constituting only $8.9 \%$ of the total apical trills collected for the study, while the remaining 174 were produced by speaker 2 , constituting $91.1 \%$ of the total trills. Of the 450 tokens for each subject, the trill emerged in only $3.7 \%$ of the total tokens for speaker 1 , while for speaker 2, the trill emerged in $38.7 \%$ of the total cases.

As regards the aerodynamic parameters specified in the model (Table 11), peak mouthflow $(p<.001)$ and average mouthflow $(p=<.002)$ are significant predictors of trilling. The posterior means for the coefficients for these variables (Max_F [-7913.8], AVG_F [0.1050060]), fall between the 95\% credibility intervals (Max_F [-13960.8] - [-2141.5], Avg_F [0.0334342] - [0.1694055]), indicating significance. A comparison of the deviance information criterion (DIC) between a model specified with peak mouthflow and one in which peak mouthflow was not specified shows an overall better fit for the former model (DIC-fully specified model [4.55]; DIC-model without peak mouthflow [123.27], 4.55 $<123.2658$ ). This procedure was repeated for average flow, obtaining similar results (DIC-fully specified model [4.55]; DIC-model without rate increase [84.77], $4.55<$ $84.77)$. These results indicate that trill distribution is predictable in part by the aerodynamic conditions of the local phonetic environment.

Concerning the temporal measures, results of the model show that the duration of the vowel + rhotic sequence $(p<.001)$, overlap $(p<.001)$ and the duration of the tongue tip gesture leading up to contact $(p=.016)$ are significant predictors of trill distribution. Again posterior means for the coefficients for each variable fall within the $95 \%$ credibility intervals (Table 11). Additionally, DIC for the fully specified models are considerably lower than those models not fitted with the temporal variables (v + rhotic sequence: DIC [97.85] unspecified model, [4.55] fully specified model; $4.55<97.85$; Duration rhotic onset: DIC [92.65] unspecified model, [4.55] fully specified model; $4.55<97.85$; Overlap: DIC [64.22] unspecified model, [4.55] fully specified model; $4.55<64.22$ ).

\section{CONCLUSIONS}

Combined results of this study indicate that the tongue posture of a preceding vowel affects the temporal organization of gestures leading up to an apical trill and the aer- 
Table 11. Summary of results for Bayesian model.

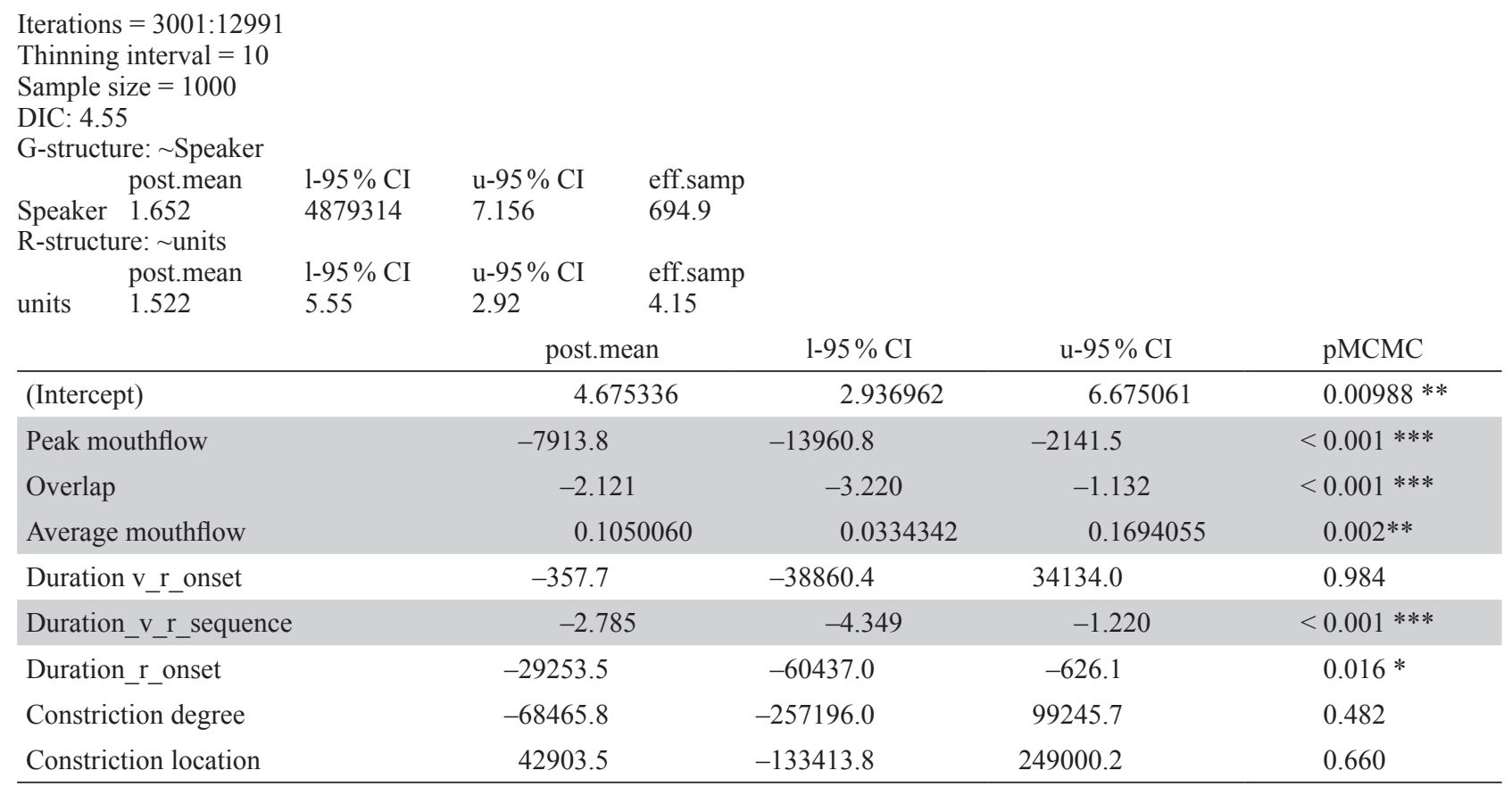

odynamic parameters which fallout therein. It was also shown that these variables (and presumably their pressure correlates) condition tap/trill variation in Spanish codas. With regard to tongue anteriority/posteriority, mid and back vowels show a shorter period of phonation before the initiation of the onset gesture for the rhotic. The more posterior posture imposes less articulatory constraint on the tongue tip. As a result the tongue tip gesture for the rhotic may initiate earlier for mid and back vowels, which results in a longer onset gesture for mid and back vowels. Front vowels, on the other hand, have longer phonation periods, and shorter onset gestures for the rhotic, possibly due to the fact that the tongue must retract slightly in order achieve the articulatory target. With regard to height, low and mid vowels (especially mid and back) have shorter phonation periods preceding tongue tip activation, which possibly results from the fact that less predorsum lowering is needed (as opposed to high vowels) in order to achieve the precise articulatory posture for the production of the rhotic. High vowels (especially front), on the other hand, show a longer phonation period before tongue tip activation, and a shorter onset gesture leading up to alveolar contact.

No significant difference was found in the timing between the onset of phonation and initial contact with the alveolar ridge (though differences in timing between taps and trills are significant). This is consistent with the results for the overlap patterns. Mid (especially back) and low vowels permit more overlap than high vowels (especially front), which is line with Recasens' (2012) results showing low vowels to be more susceptible to coarticulation than high vowels. Although the timing of the gestures vary as a function of the tongue posture of the pre- ceding vowel, the results show that the global timing of the vowel + rhotic sequence remains stable.

Tongue posture of the preceding vowel was found to affect the aerodynamic patterns of the rhotic onset as well. As for the effects of tongue anteriority, the mid and back vowels had higher mouthflow peaks and faster average flow than front vowels. Tongue height as well affects peak flow, high vowels having the lowest maxima, but no main effect of tongue height was found for average mouthflow.

Significant differences in the temporal and aerodynamic parameters of taps and trills were found as well. Trills have higher overlap than taps, with longer onsets and longer overall durations for the vowel and onset gesture sequences than taps. Peak mouthflow for trills was considerably higher than for taps, while average flow leading up to alveolar contact was faster in trills than in taps.

No significant effects on the temporal and aerodynamic variables were found for the following consonant. This should not be interpreted, however, as evidence that the following consonant does not affect the aerodynamic and temporal parameters of trills and taps. This study dealt with a limited set of measures which pertained to the rhotic onset. A detailed analysis of the closure and postclosure phase of taps and trills is currently in progress. Further, this study only dealt with the effects of voiced and voiceless stops in order to construct an initial model of tap/trill variation. In the future, it is planned to augment the models created for this study to include all constriction degree and constriction location specifications.

By collapsing the factors reflecting tongue posture of the preceding vowel into singular vowel categories $(/ \mathrm{i} /$, /e/, /a/, /o/, /u/), a preference emerges between spontane- 
ous trilling following [a] and [o], which may be related to the similarities in the articulatory settings, especially in the predorsum region, between trills and low mid and back vowels. Since the position of the tongue body is already low for the production of [a], minimal predorsum lowering is needed in order to achieve the articulatory setting required for trilling. At the same time, the concentration of tongue body action in the mid section of the oral cavity translates to a less constrained tongue tip (as it would for back articulation for posterior vowels as well). These articulatory postures lead to a more fluid coupling of the vowel and rhotic gestures, attested in the overlap patterns presented in this article.

Finally, from a theoretical perspective, the models in this study show that trill distribution in Spanish codas can be explained without having to resort to structural constraints for which there is very little evidence. Trilling in coda ensues when there is a high degree of overlap between the vowel and onset gesture of the following rhotic (after approximately $78 \%$, odds of trilling increase linearly with overlap), and when mouthflow (and corresponding intraoral pressure parameters) reaches a certain threshold (at $0.181 \mathrm{dm}^{3} / \mathrm{s}$ [pooled means] odds of trilling increase linearly with mouthflow). It was shown that both of these parameters are functions of the different tongue body specifications of the preceding vowel, meaning trilling is more probable in certain phonetic environments. Although it was shown that these thresholds may be reached in any vocalic context, certain vowel environments favor the attainment of these parameters. By including this element of randomness, it leads the way to account for the effects of other variables such as speech rate, style and a range of prosodic effects which may also condition rhotic variation in coda.

\section{REFERENCES}

Alonso, A. (1945). Una ley fonológica del español. Hispanic Review, 13(2), 91-101.

Arbisi-Kelm, T., Beckman, M., Kong, E., \& Edwards, J. (2008). Psychoacoustic measures of stop production in Cantonese, Greek, English, Japanese, and Korean. The Journal of the Acoustical Society of America, 124, 2556. http://dx.doi. org/10.1121/1.4783033

Avram, A. (1993). Cercetări experimentale asupra consoanelor lichide din limba română [Experimental research on liquid consonants in Romanian]. Fonetică și dialectologie, 12, 8-20.

Baltazani, M., \& Nicolaidis, K. (2011). Production of the Greek rhotic in initial and intervocalic position: An acoustic and electropalatographic study. In Z. Gavriilidou, A. Efthymiou, E. Thomadaki, \& P. Kambakis-Vougiouklis (Eds.), Selected papers of the 10th International Conference on Greek Linguistics (pp. 141-152). Komotini, Greece: Democritus University of Thrace.

Baltazani, M., \& Nicolaidis, K. (2013). The many faces of /r/. In L. Spreafico \& A. Vietti (Eds.), Rhotics: New data and perspectives (pp. 125-144). Bozen: University of Bozen-Bolzano. Retrieved from http://www.unibz.it/it/library/Documents/bupress/ publications/fulltext/9788860460554.pdf

Barry, W. J. (1997). Another R-tickle. Journal of the International Phonetic Association, 27(1-2), 35-45. http://dx.doi. org/10.1017/S0025100300005405
Bates, D., Maechler, M., Bolker, B., \& Walker, S. (2015). Ime4: Linear mixed-effects models using Eigen and S4. Retrieved from https://CRAN.R-project.org/package=lme4

Beckman, J. N. (1998). Positional faithfulness (Doctoral dissertation, University of Massachusetts Amherst). Retrieved from http://roa.rutgers.edu/files/234-1297/234-1297-BECKMAN-6-0.PDF

Blecua, B. (2001). Las vibrantes del español: Manifestaciones acústicas y procesos fonéticos (Doctoral dissertation, Universitat Autònoma de Barcelona). Retrieved from http://hdl.handle. net/10803/4859

Bloomfield, L. (1956). Eastern Ojibwa: Grammatical sketch, texts, and word list. University of Michigan Press.

Bradley, T. G., \& Schmeiser, B. S. (2003). On the phonetic reality of $/ \mathbf{r} /$ in Spanish complex onsets. In P. M. Kempchinsky \& C. E. Piñeros (Eds.), Theory, practice and acquisition (pp. 1-20). Somerville, MA: Cascadilla Press.

Bradley, T. G., \& Willis, E. W. (2012). Rhotic variation and contrast in Veracruz Mexican Spanish. Estudios de Fonética Experimental, 21, 43-74.

Browman, C. P., \& Goldstein, L. M. (1986). Towards and articulatory phonology. Phonology, 3, 219-252. http://dx.doi. org/10.1017/S0952675700000658

Browman, C. P., \& Goldstein, L. M. (1995). Gestural syllable position effects in American English. In F. Bell-Berti \& L. J. Raphael (Eds.), Producing speech: Contemporary issues for K. S. Harris (pp. 19-33). New York: AIP Press.

Byrd, D. (1996). Influences on articulatory timing in consonant sequences. Journal of Phonetics, 24, 209-244.

Canfield, D. L. (1960). Observaciones sobre el español salvadoreño. Filología, 6, 29-76.

Canfield, D. L. (1981). Spanish pronunciation in the Americas. University of Chicago Press.

Catford, J. C. (1977). Fundamental problems in phonetics. Edinburgh University Press.

Chang, S. S., Ohala, J. J., Hansson, G., James, B., Lewis, J., Liaw, L., . . . Van Bik, K. (1999). Vowel-dependent VOT variation: An experimental study. Journal of the Acoustical Society of America, 105, 1400. http://dx.doi.org/10.1121/1.426611

Colina, S. (2010). Rhotics in Spanish: A new look at an old problem. In C. Borgonovo, M. Español-Echevarría, \& P. Prévost (Eds.), Selected Proceedings of the 12th Hispanic Linguistics Symposium (pp. 75-86). Somerville, MA: Cascadilla Proceedings Project.

Darias Concepción, J. L., Ruisánchez Regalado, M. d. C., \& Dohotaru, P. (1997). El proceso de la velarización del fonema nasal distensivo en el español de Pinar del Río-Enfoque sociolingüístico.

Romanistisches Jahrbuch, 48(1), 287-295. http://dx.doi.org/10.1515/ roja-1997-0143

Davis, B. L., \& MacNeilage, P. F. (1995). The articulatory basis of babbling. Journal of Speech, Language, and Hearing Research, 38, 1199-1211. http://dx.doi.org/10.1044/jshr.3806.1199

Demuth, K., \& Fee, E. J. (1995). Minimal prosodic words in early phonological development. Unpublished manuscript, Brown University and Dalhousie University.

D’Introno, F., Rojas, N., \& Sosa, J. M. (1979). Estudio sociolingüístico de las líquidas en posición final de sílaba y final de palabra en el español de Caracas. Boletín de la Academia Portorriqueña de la Lengua Española, 7(2), 59-100.

Fikkert, P. (1994). On the acquisition of prosodic structure (Doctoral dissertation, Rijksuniversiteit Leiden). Retrieved from http://hdl.handle.net/2066/32125.

Fischer-Jørgensen, E. (1972). Tape-cutting experiments with Danish stop consonants in initial position. Annual Report of the Institute of Phonetics, University of Copenhagen, 6, 104-168.

Fougeron, C. (1999). Prosodically conditioned articulatory variation: A review. UCLA Working Papers in Phonetics, 97, 1-73.

Fox, J. (2008). Applied regression analysis and generalized linear models (2nd ed.). Los Angeles, CA: Sage.

Fox, J., \& Weisberg, S. (2011). An R Companion to Applied Regression, Second Edition. Thousand Oaks, CA: Sage. Retrieved from http://socserv.socsci.mcmaster.ca/jfox/Books/Companion 
Gelman, A. (2008). Objections to Bayesian statistics. Bayesian Analysis, 3, 445-450. http://dx.doi.org/10.1214/08-BA318

Gelman, A. (in press). Regression: What's it all about? Statistics in Medicine. Retrieved from http://www.stat.columbia.edu/ gelman/ research/published/wakefield_regression.pdf

Gnanadesikan, A. E. (1996). Markedness and faithfulness constraints in child phonology. University of Massachusetts Amherst.

Goldstein L., Byrd, D., \& Saltzman, E. (2006). The role of vocal tract gestural action in units in understanding the evolution of phonology. In M. A. Arbib (Ed.), Action to language via the mirror neuron system, 215-249. Cambridge, UK: Cambridge University Press. http://dx.doi.org/10.1017/CBO9780511541599.008

Goldstein, L., Nam, H., Saltzman, E., \& Chitoran, I. (2008, April). Coupled oscillator planning model of speech timing and syllable structure. Paper presented at the 8th Phonetics Conference of China and the International Symposium on Phonetic Frontiers, Beijing. Retrieved from http://sail.usc.edu/ lgoldste/ArtPhon/Papers/save/Week \%2012/LG_final.pdf

Goldstein, L., Pouplier, M., Chen, L., Saltzman, E, \& Byrd, D. (2007). Dynamic action units slip in speech production errors. Cognition, 103(3), 386-412. http://dx.doi.org/10.1016/j. cognition.2006.05.010

González, C. (2002). Phonetic variation in voiced obstruents in North-Central Peninsular Spanish. Journal of the International Phonetic Association, 32(1), 17-31. Cambridge, UK: Cambridge University Press. http://dx.doi.org/10.1017/S0025100302000129

Gudurić, S., \& Petrović, D. (2005). О природи гласа /r/ у српском језику [The nature of the sound $[\mathrm{r}]$ in the Serbian language]. Зборник Матице српске за филологију и лингвистику, 48(1-2), 135-150.

Hadfield, J. D. (2010). MCMC methods for multi-response generalized linear mixed models: The MCMCglmm R package. Journal of Statistical Software, 33(2), 1-22. Retrieved from http:// www.jstatsoft.org/v33/i02/.

Hall, N. (2006). Cross-linguistic patterns of vowel intrusion. Phonology, 23(3), 387-429. http://dx.doi.org/10.1017/ S0952675706000996

Harms, R. T. (1976). The segmentalization of Finnish nonrules. Texas Linguistic Forum, 5, 73-88.

Hothorn, T., Bretz, F., \& Westfall, P. (2008). Simultaneous inference in general parametric models. Biometrical Journal, 50(3), 346-363. http://dx.doi.org/10.1002/bimj.200810425

Hualde, J. I. (2004). Quasi-phonemic contrasts in Spanish. In V. Chand, A. Kelleher, A. J. Rodríguez, \& B. Schmeiser (Eds.), WCCFL 23: Proceedings of the 23rd West Coast Conference on Formal Linguistics (pp. 374-398). Somerville, MA: Cascadilla Press.

Huinck, W. J., van Lieshout, P. H. H. M., Peters, H. F. M., \& Hulstijn, W. (2004). Gestural overlap in consonant clusters: Effects on the fluent speech of stuttering and non-stuttering subjects. Journal of Fluency Disorders, 29(1), 3-25. http://dx.doi. org/10.1016/j.jfludis.2003.09.001

Isshiki, N. (1964). Regulatory mechanism of voice intensity variation. Journal of Speech, Language, and Hearing Research, 7 , 17-29. http://dx.doi.org/10.1044/jshr.0701.17

Kirchner, R. M. (1998). An effort-based approach to consonant lenition (Doctoral Dissertation, University of California). Retrieved from http://roa.rutgers.edu/files/276-0898/roa276-kirchner-2.pdf

Klatt, D. (1975). Voice onset time, frication, and aspiration in wordinitial consonant clusters. Journal of Speech, Language, and Hearing Research, 18, 686-706. http://dx.doi.org/10.1044/ jshr.1804.686

Kochetov, A., \& Colantoni, L. (2011). Coronal place contrasts in Argentine and Cuban Spanish: An electropalatographic study. Journal of the International Phonetic Association, 41(3), 313342. http://dx.doi.org/10.1017/S0025100311000338

Koenig, L. \& Fuchs, S. (2007). The sensitivity of intraoral pressure in consonants and consonant clusters to following vowel context in German. In Proceedings of the 16th International Congress of Phonetic Sciences (ICPhS 16-Saarbrücken, Germany), 641-644.
Laboratoire Parole \& Langage (2014). Phonedit Signaix [4.2.0.1]. Université d'Aix-enProvence. Retrieved from http://www.lplaix.fr/ lpldev/phonedit/download.html

Ladefoged, P., \& Maddieson, I. (1996). The sounds of the world's languages. Oxford: Blackwell.

Levelt, C. C., Schiller, N. O., \& Levelt, W. J. (2000). The acquisition of syllable types. Language Acquisition, 8(3), 237-264. http://dx.doi.org/10.1207/S15327817LA0803_2

Levin, J. (1987). Between epenthetic and excrescent vowels. In M. Crowhurst (Ed.), WCCFL 6: The Proceedings of the Sixth West Coast Conference on Formal Linguistics (pp. 187-201). Standford, CA: CSLI.

Lipski, J. (1987). Fonética y fonología del español de Honduras. Tegucigalpa: Guaymuras.

Lipski, J (1994). Latin American Spanish. New York: Longman.

López Morales, H. (1981). Velarization of /n/ in Puerto Rican Spanish. In D. Sankoff and H. Cedergren (Eds.), Variation omnibus (pp. 105-113). Edmonton, Canada: Linguistic Research.

López Morales, H. (1983). Estratificación social del español de San Juan de Puerto Rico. México D. F.: UNAM.

MacNeilage, P. F. (1998). The frame/content theory of evolution of speech production. Behavioral and Brain Sciences, 21(4), 499511. http://dx.doi.org/10.1017/S0140525X98001265

MacNeilage, P. F., \& Davis, B. L. (1990). Acquisition of speech production: The achievement of segmental independence. In W. J. Hardcastle \& A. Marchal (Eds.), Speech production and speech modeling (pp. 55-68). Dordrecht: Kluwer.

Marrero Aguiar, V. (1988). Fonética estática y fonética dinámica en el habla de las Islas Canarias. Madrid: Universidad Complutense.

Netsell, R., Lotz, W. K., DuChane, A. S., \& Barlow, S. M. (1991). Vocal tract aerodynamics during syllable productions: Normative data and theoretical implications. Journal of Voice, 5(1), 1-9. http://dx.doi.org/10.1016/S0892-1997(05)80157-2

Ohala, J. J., \& Kawasaki, H. (1984). Prosodic phonology and phonetics. Phonology, 1, 113-127. http://dx.doi.org/10.1017/ S0952675700000312

Pavlík, R. (2008). K niektorým otázkam kvalitatívnych a kvantitatívnych vlastností slovenských vibrant [To the question of qualitative and quantitative characteristics of the Slovak vibrant consonants]. Jazykovedný časopis, 52(1-2), 65-97.

Pouplier, M. (2007a). Articulatory perspectives on errors. In C.T. Schütze \& V.S. Ferreira (Eds.), The state of the art in speech error research: Proceedings of the Linguistic Society of America Summer Institute, Workshop. MIT Working Papers in Linguistics, 53 (pp. 115-132). Cambridge, MA: MITWPL.

Pouplier, M. (2007b). Tongue kinematics during utterances elicited with the SLIP technique. Language and Speech, 50(3), 311341. http://dx.doi.org/10.1177/00238309070500030201

Proctor, M. I., Shadle, C. H., \& Iskarous, K. (2010). Pharyngeal articulation in the production of voiced and voiceless fricatives. Journal of the Acoustical Society of America, 127(3), 15071518. http://dx.doi.org/10.1121/1.3299199

Quilis, A. (1970). El elemento esvarabático en los grupos [pr, br, tr]. In Phonétique et Linguistique Romanes: Mélanges offerts à M. Georges Straka (Vol. 1, pp. 99-104). Lyon-Strasbourg: Société de Linguistique Romane.

Quilis, A. (1993). Tratado de fonología y fonética españolas (1st ed.) Madrid: Gredos.

Quilis, A. (1999). Tratado de fonología y fonética españolas (2nd ed.). Madrid: Gredos.

Quilis-Sanz, M. J. (1998). Las consonantes [-r] y [-1] implosivas en Andalucía. Revista de Filología Española, 78(1-2), 125-156. http://dx.doi.org/10.3989/rfe.1998.v78.i1/2.301

Ramírez, C. J. (2006). Acoustic and perceptual characterization of the epenthetic vowel between the clusters formed by consonant + liquid in Spanish. In M. Díaz-Campos (Ed.), Selected proceedings of the Second Conference on Laboratory Approaches to Spanish Phonetics and Phonology (pp. 48-61). Somerville, MA: Cascadilla Proceedings Project.

Recasens, D. (1985). Coarticulatory patterns and degrees of coarticulatory resistance in Catalan CV sequences. Language and Speech, 28, 97-114. 
Recasens, D. (1987). An acoustic analysis of V-to-C and V-to-V coarticulatory effects in Catalan and Spanish VCV sequences. Journal of Phonetics, 15, 299-312.

Recasens, D. (1991). On the production characteristics of apicoalveolar taps and trills. Journal of Phonetics, 19, 267-280.

Recasens, D. (2004). The effect of syllable position on consonant reduction (evidence from Catalan consonant clusters). Journal of Phonetics, 32(2), 435-453. http://dx.doi.org/10.1016/j. wocn.2004.02.001

Recasens, D. (2012). A study of jaw coarticulatory resistance and aggressiveness for Catalan consonants and vowels. Journal of the Acoustical Society of America, 132, 412-420. http://dx.doi. org/10.1121/1.4726048

Recasens, D., \& Espinosa, A. (2007). Phonetic typology and positional allophones for alveolar rhotics in Catalan. Phonetica, 64, 1-28. http://dx.doi.org/10.1159/000100059

Recasens, D., \& Pallarès, M. D. (1999). A study of $/ \mathrm{r} /$ and $/ \mathrm{r} /$ in the light of the 'DAC' coarticulation model. Journal of Phonetics, 27(2), 143-169. http://dx.doi.org/10.1006/jpho.1999.0092

Romero, J. (1995). An articulatory view of historical s-aspiration in Spanish. Haskins Laboratories Status Report on Speech Research, 1994-1995. SR-119/120, 255-266.

Romero, J. (1996). Articulatory blending of lingual gestures. Journal of Phonetics, 24(1), 99-111. http://dx.doi.org/10.1006/ jpho.1996.0007

Salidis, J., \& Johnson, J. S. (1997). The production of minimal words: A longitudinal case study of phonological development. Language Acquisition, 6(1), 1-36. http://dx.doi.org/10.1207/ s15327817la0601 1

Schmeiser, B. (2009). An acoustic analysis of intrusive vowels in Guatemalan Spanish $/ \mathrm{rC}$ / clusters. University of Pennsylvania Working Papers in Linguistics, 15(1), article 22.

Shadmehr, R., \& Arbib, M. A. (1992). A mathematical analysis of the force-stiffness characteristics of muscles in control of a single joint system. Biological Cybernetics, 66(6), 463-477. http:// dx.doi.org/10.1007/BF00204111

Solé, M.-J. (2002). Aerodynamic characteristics of trills and phonological patterning. Journal of Phonetics, 30, 655-688. http:// dx.doi.org/10.1006/jpho.2002.0179
Solé, M.-J. (2003). Aerodynamic characteristics of onset and coda fricatives. 15th International Congress of Phonetic Sciences (ICPhS 15-Barcelona, Spain), 2761-2764.

Spajić, S., Ladefoged, P., \& Bhaskararao, P. (1996). The trills of Toda. Journal of the International Phonetic Association, 26(1), 1-21. http://dx.doi.org/10.1017/S0025100300005296

Stevens, K. N. (1972). The quantal nature of speech: Evidence from articulatory-acoustic data. In E. E. David Jr. \& P. B. Denes (Eds.), Human communication: A unified view (pp. 51-66). New York: McGraw-Hill.

Stevens, K. N. (1989). On the quantal nature of speech. Journal of Phonetics, 17, 3-45.

Stolarski. Ł. (2011, June). Vocalic elements in the articulation of the Polish and English $/ r$. Paper presented at Languages in Contact, University of Wrocław, Poland.

Vago, R. M., \& Gósy, M. (2007). Schwa vocalization in the realization of $/ \mathrm{r} /$. In Proceedings of the 16th International Congress of Phonetic Sciences (ICPhS 16-Saarbrücken, Germany), 505-509.

Vásquez Carranza, L. M. (2006). On the phonetic realization and distribution of Costa Rican rhotics. Filología y Lingüistica, 32 (2), 291-309.

Vihman, M. M., \& Ferguson, C. A. (1987). The acquisition of final consonants. In Proceedings of the 11th International Congress of Phonetic Sciences (ICPhS 11-Tallinn, Estonia), 381-384.

Warner, N., Jongman, A., Cutler, A., \& Mücke, D. (2001). The phonological status of Dutch epenthetic schwa. Phonology, 18(3), 387-420. http://dx.doi.org/10.1017/S0952675701004213

Willis, E. W. (2006). Trill variation in Dominican Spanish: An acoustic examination and comparative analysis. In N. Sagarra \& A. J. Toribio (Eds.), Selected proceedings of the 9 th Hispanic Linguistics Symposium (Vol. 1, pp. 121-131). Somerville, MA: Cascadilla Proceedings Project.

Wireback, K. J. (1999). On the word-internal velarization of $/ \mathrm{n} /$ in Cuban radio broadcasting. In J. Gutiérrez-Rexach \& F. Martínez-Gil (Eds.), Advances in Hispanic Linguistics: Papers from the 2nd Hispanic Symposium (Vol. 1, pp. 291-300). Somerville, MA: Cascadilla Press. 